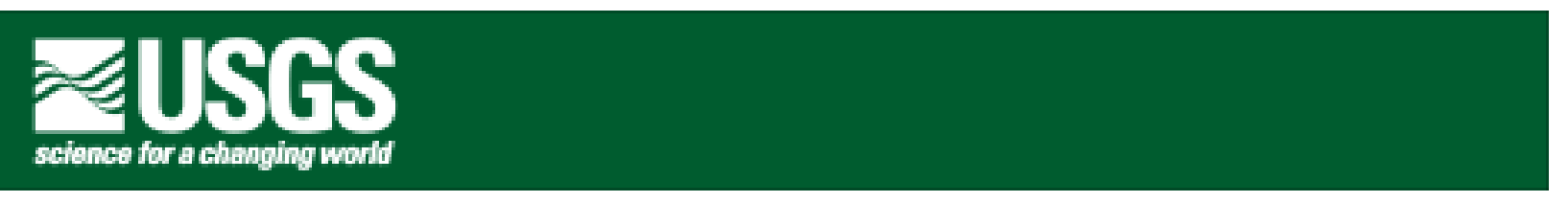

\title{
Gravity and Magnetic Study of the Pahute Mesa and Oasis Valley Region, Nye County, Nevada
}

By Edward A. Mankinen ${ }^{1}$, Thomas G. Hildenbrand ${ }^{1}$, Gary L. Dixon ${ }^{2}$, Edwin H. McKee $^{1}$, Christopher J. Fridrich ${ }^{3}$, and Randell J. Laczniak ${ }^{2}$

Open-File Report 99-303

Version 1.0

Prepared in cooperation with the

U.S. DEPARTMENT OF ENERGY

NEVADA OPERATIONS OFFICE

(Interagency Agreement DE-AI08-96NV11967)

1999

This report is preliminary and has not been reviewed for conformity with U.S. Geological Survey editorial standards or with the North American Stratigraphic Code. Any use of trade, firm, or product names is for descriptive purposes only and does not imply endorsement by the U.S. Government.

\section{U.S. DEPARTMENT OF THE INTERIOR U.S. GEOLOGICAL SURVEY}

${ }^{1}$ Menlo Park, California 94025; ${ }^{8}$ Las Vegas, Nevada 89119, ${ }^{3}$ Denver, Colorado 80225 


\section{TABLE OF CONTENTS}

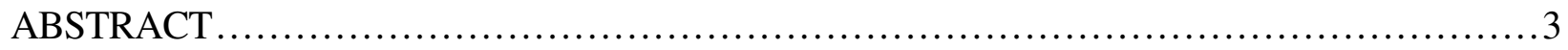

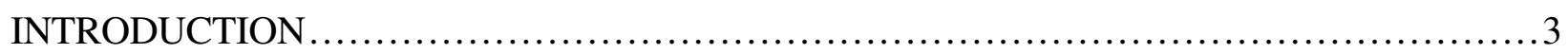

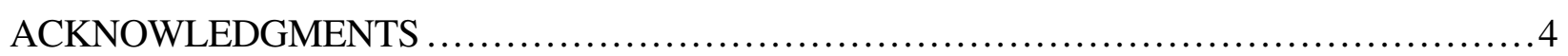

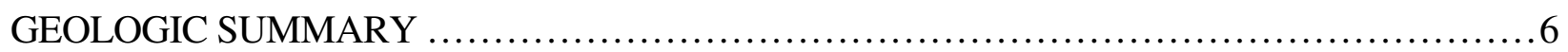

REGIONAL GEOPHYSICAL FEATURES ...............................................

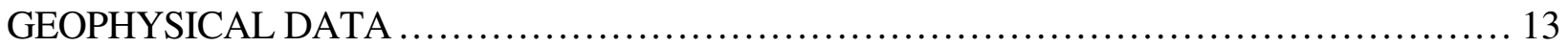

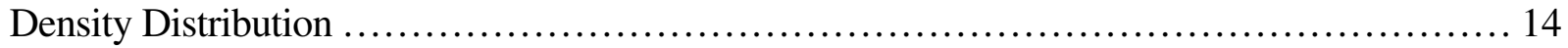

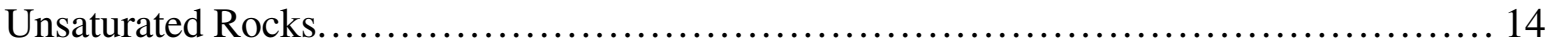

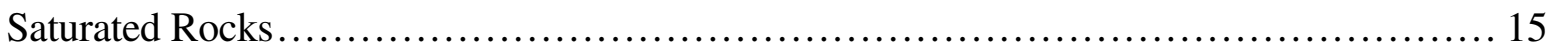

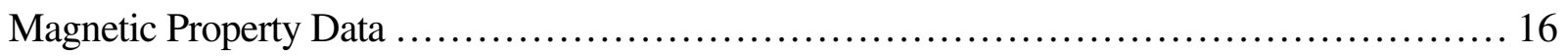

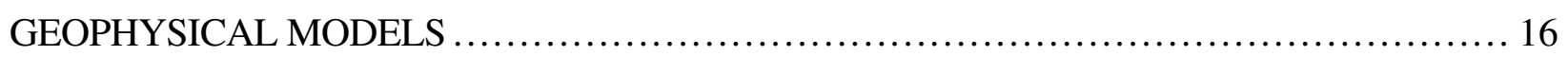

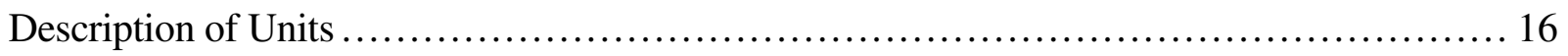

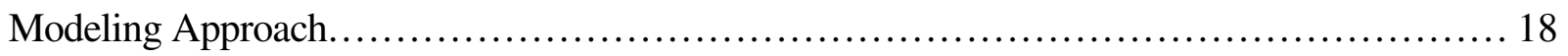

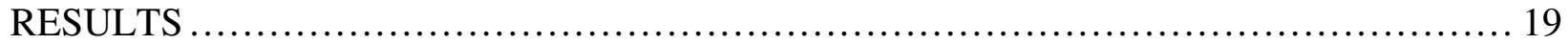

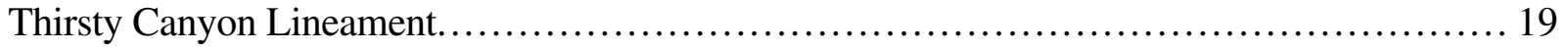

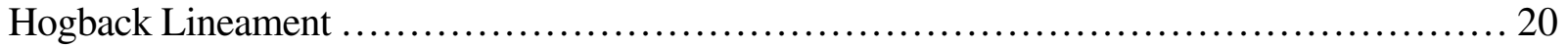

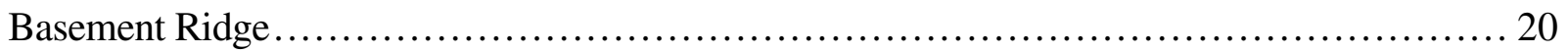

Colson Pond Lineament.................................................................. 20

Fleur-De-Lis Lineament................................................................. 27

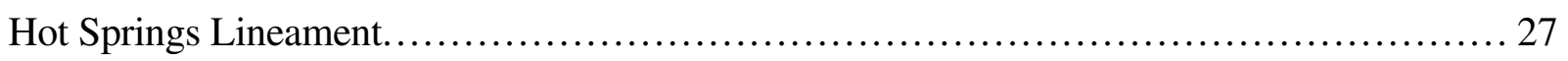

Southern Margin of the Oasis Valley Basin.................................................... 27

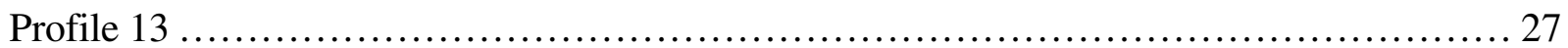

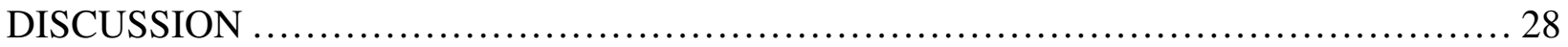

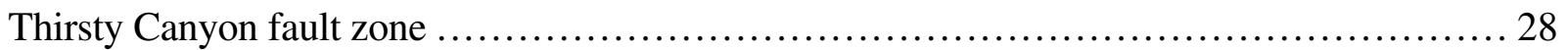

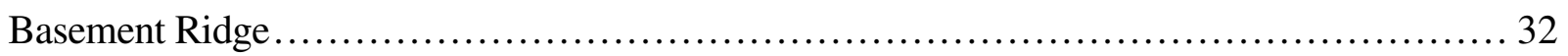

Oasis Valley Basin................................................................. 35

Colson Pond accommodation zone .................................................... 35

Hot Springs accommodation zone .................................................... 35

Hogback fault ....................................................................... 35

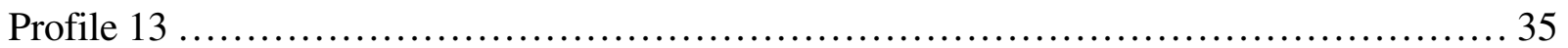

POTENTIAL GEOHYDROLOGIC IMPLICATIONS OF INFERRED STRUCTURES......... 36

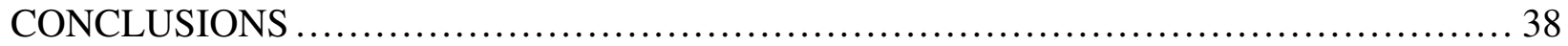

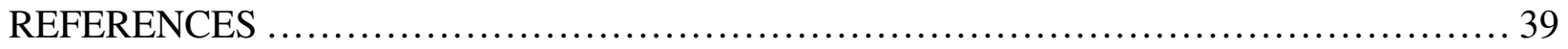

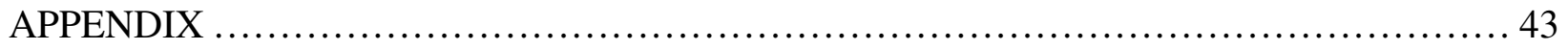




\section{ILLUSTRATIONS}

Figure 1. Isostatic residual map of the Pahute Mesa - Oasis Valley area.........................5

Figure 2. Map showing location and informal names of gravity anomalies, and location of

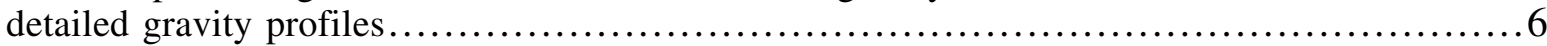

Figure 3. Map showing inferred boundaries of known calderas in the central southwest

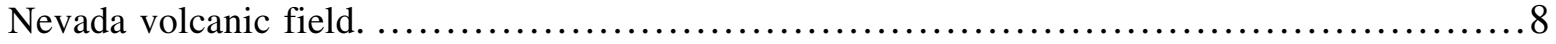

Figure 4. Generalized volcanic stratigraphy of Pahute Mesa - Oasis Valley ................... 10

Figure 5. Thickness of Cenozoic volcanic rocks and sedimentary deposits ................... 11

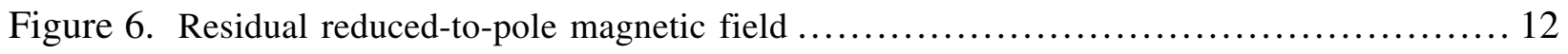

Figure 7. Magnetic potential field ............................................... 13

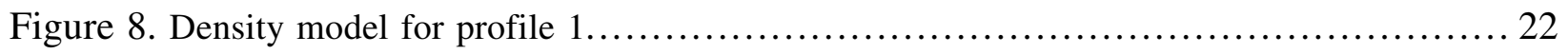

Figure 9. Density models for profiles crossing the Thirsty Canyon lineament................... 23

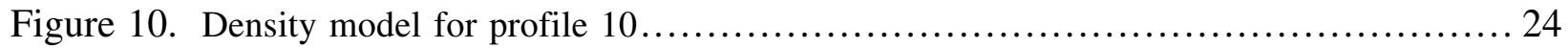

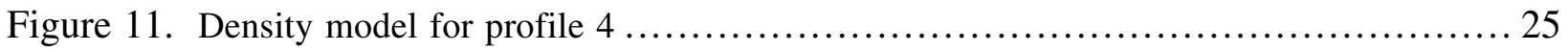

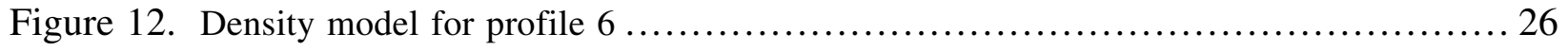

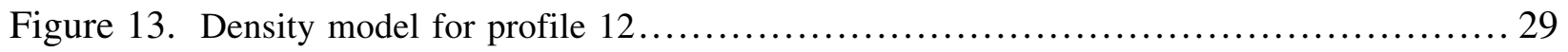

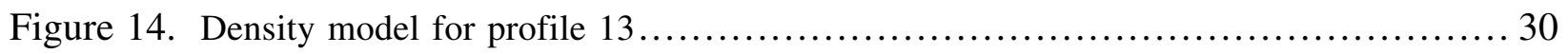

Figure 15. Geologic interpretation of subsurface structures crossing the Thirsty Canyon

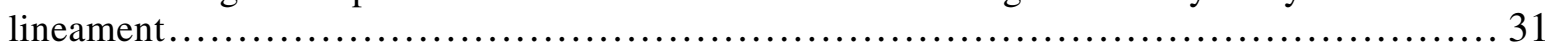

Figure 16. Location of micro-earthquakes in the Pahute Mesa area ....................... 33

Figure 17. Geologic interpretation of subsurface structure along profile 4 ................... 34

Figure 18. Gravity lineaments, the Thirsty Canyon fault zone, and possible relationships to ground-water flow in the study area

\section{TABLE}

Table 1. Density and magnetization of rocks from the Pahute Mesa - Oasis Valley region ....... 18 


\section{ABSTRACT}

Regional gravity and aeromagnetic maps reveal the existence of deep basins underlying much of the southwestern Nevada volcanic field, approximately $150 \mathrm{~km}$ northwest of Las Vegas. These maps also indicate the presence of prominent features (geophysical lineaments) within and beneath the basin fill. Detailed gravity surveys were conducted in order to characterize the nature of the basin boundaries, delineate additional subsurface features, and evaluate their possible influence on the movement of ground-water. Geophysical modeling of gravity and aeromagnetic data indicates that many of the features may be related to processes of caldera formation. Collapse of the various calderas within the volcanic field resulted in dense basement rocks occurring at greater depths within caldera boundaries. Modeling indicates that collapse occurred along faults that are arcuate and steeply dipping. There are indications that the basement in the western Pahute Mesa - Oasis Valley region consists predominantly of granitic and/or fine-grained siliceous sedimentary rocks that may be less permeable to groundwater flow than the predominantly fractured carbonate rock basement to the east and southeast of the study area. The northeasttrending Thirsty Canyon lineament, expressed on gravity and basin thickness maps, separates dense volcanic rocks on the northwest from less dense intracaldera accumulations in the Silent Canyon and Timber Mountain caldera complexes. The source of the lineament is an approximately 2-km wide ring fracture system with step-like differential displacements, perhaps localized on a pre-existing northeast-trending Basin and Range fault. Due to vertical offsets, the Thirsty Canyon fault zone probably juxtaposes rock types of different permeability and, thus, it may act as a barrier to ground-water flow and deflect flow from Pahute Mesa along its flanks toward Oasis Valley. Within the Thirsty Canyon fault zone, highly fractured rocks may serve also as a conduit, depending upon the degree of alteration and its effect on porosity and permeability. In the Oasis Valley region, other structures that may influence ground-water flow include the western and southern boundaries of the Oasis Valley basin, where the basement abruptly shallows.

\section{INTRODUCTION}

The Nevada Test Site (NTS) was the primary location for testing nuclear devices within the United States from the early 1950's until September, 1992. After enactment of the Limited Test Ban Treaty of 1963, all testing was performed underground to minimize the possibility of release of radioactive materials into the atmosphere, and many of these were detonated near or below the water table. As a consequence, many highly toxic and long-lived contaminants exist in the subsurface of the NTS. Loss of containment of these hazardous materials would most likely be by movement of ground-water (Laczniak and others, 1996). Elevated tritium levels were found in well PM-2 (Russell and Locke, 1996), 270 meters from the closest nuclear test (the 1968 Schooner test). Traces of plutonium also have been found in well ER-20-5 (Kersting and others, 1999), 1.3 $\mathrm{km}$ south of the 1968 Benham nuclear test. Although tritium is soluble in water, other radioactive products of nuclear testing partition strongly to non-aqueous-phase materials. Kersting and others (1999) demonstrate that even some non-soluble products, such as plutonium, are mobile, probably by attaching to colloids. Ground-water within this region is the western part of the Death Valley ground-water-flow system (Laczniak and others, 1996). Water from Pahute Mesa, northwestern NTS, is thought to flow south and southwest, discharging at Oasis Valley, Amargosa Desert, and ultimately, Death Valley.

Regional gravity and aeromagnetic maps of the Pahute Mesa and Oasis Valley region (McCafferty and Grauch, 1997; Ponce, 1997) reveal deep basins underlying a large part of the area. A revised gravity anomaly map based on data from Ponce (1997) and Mankinen and others (1998) is shown in figure 1, and this area will be referred to as the study area. The basin underlying eastern Pahute Mesa was shown in the interpretive cross-sections produced by Ferguson and others (1994), who used lithologic logs from boreholes along with available gravity and seismic data. The locations and dimensions of all the basins within the study area are shown on a basin thickness map by Hildenbrand and others (1999). Our investigation expands on a 
regional interpretative study by Grauch and others (1999) by more closely defining the nature of the basin boundaries and several other prominent regional features with differing structural grain that are apparent on the regional basin thickness map of Hildenbrand and others (1999). Some of the features and localities to be discussed in this report are shown in figure 2. Gravity (Ponce, 1997; Mankinen and others, 1998) and aeromagnetic (McCafferty and Grauch, 1997) data, results from a concurrent magnetotelluric (MT) study (Schenkel, 1998; Schenkel and others, 1999), and new geologic mapping (C.J. Fridrich, unpublished data, 1999) are used to develop new tectonic models of the subsurface. Other useful geologic information in the vicinity of our profiles are the geologic cross sections generated by Byers and Cummings (1966), O'Conner and others (1966), Christiansen and Noble (1968), Orkild and others (1969), Byers and others (1976a, b), Scott and Bonk (1984), Frizzell and Shulters (1990), and Minor and others (1997). The models of the subsurface by Ferguson and others (1994), and the geologic and hydrologic sections of Laczniak and others (1996) were also valuable. Results are intended to provide constraints in the development of conceptual and numerical models of ground-water flow and to aid in monitoring efforts.

\section{ACKNOWLEDGMENTS}

We thank J.E. Magner and D.A. Trudeau of the USGS (Las Vegas) for arranging the logistics on the Nevada Test Site and for facilitating our work there. Officials at the Nellis Air Force Range were very accommodating by allowing the access necessary to complete this study. Thanks, also, to landowners Glenn Coffer and David Spicer for access to their properties. C.W. Roberts and J.G. Davidson provided valuable assistance in the field and with the data processing. Discussions with D.C. Buesch, V.E. Langenheim, R.L. Morin, and J.M. Thomas were very helpful. We also appreciate the helpful reviews and informal comments by S.L. Drellack, B. Hurley, G.A. Pawloski, D.A. Ponce, M.J. Townsend and W. Hawkins. This investigation was conducted as part of an interagency effort between the USGS and the U.S. Department of Energy (DOE) under Interagency Agreement DE-AI08-96NV11967. 


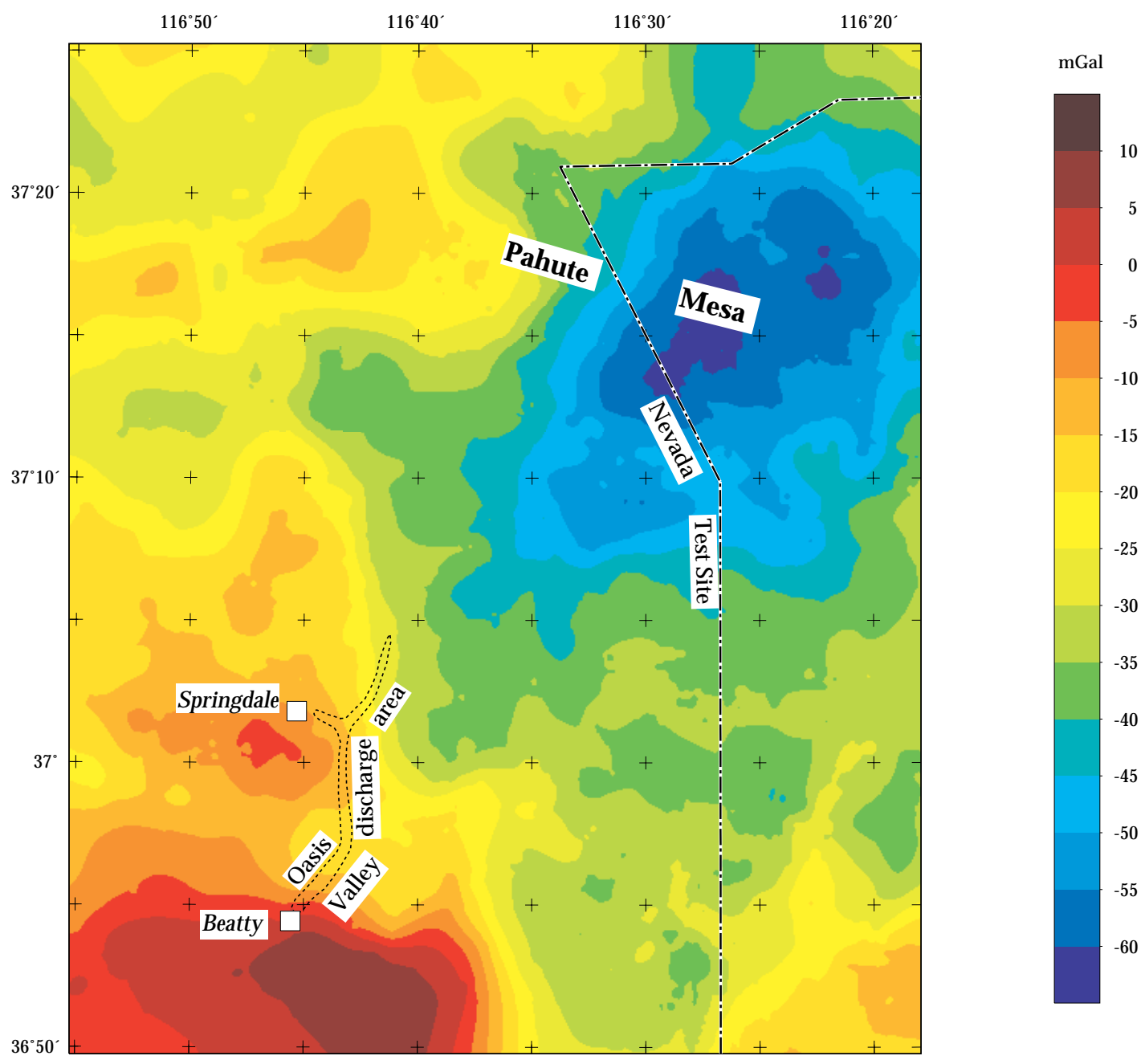

$25 \mathrm{KM}$

Figure 1. Isostatic residual gravity map of the Pahute Mesa - Oasis Valley area. All available gravity data were normalized using a reduction density of $2400 \mathrm{~kg} / \mathrm{m}^{3}$. 


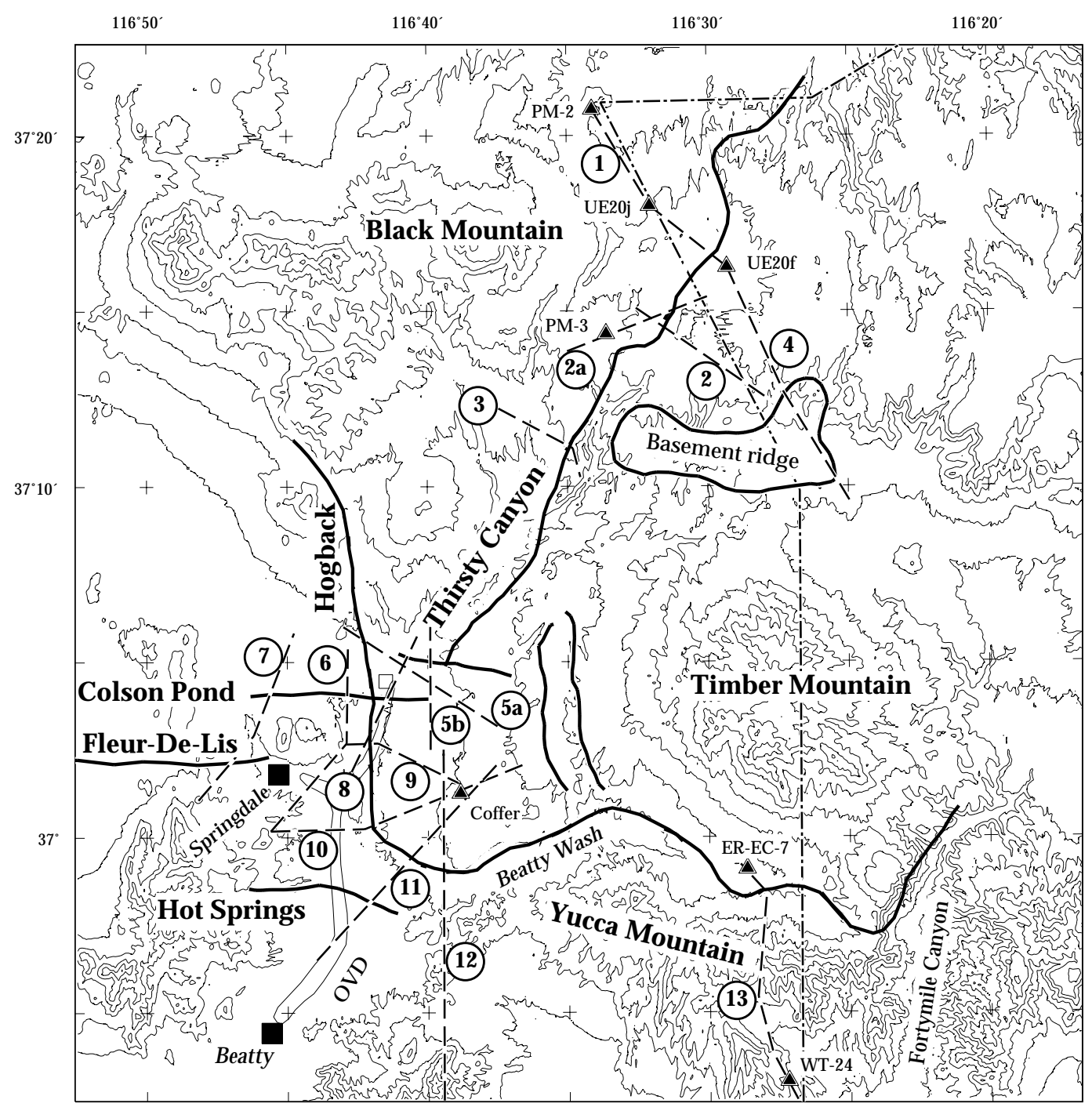

$25 \mathrm{KM}$

Figure 2. Map showing locations and informal names of gravity lineaments (solid lines), gravity profiles (numbered, dotted lines), the Oasis Valley discharge area (OVD), and other localities mentioned in the text. Contour interval is 100 meters.

\section{GEOLOGIC SUMMARY}

What is now southern Nevada was near the western edge of the North American craton of Precambrian and lower and middle Paleozoic times. Major rock types from this time consist of Upper Precambrian to Lower Cambrian terrigenous siliceous detrital deposits, overlain mostly by massive carbonate rocks. The major depositional provinces and tectonic activity shifted northwest of the study area during the latter part of the Paleozoic Era, with volumetrically smaller amounts of 
sediment being deposited up to the end of Early Permian time. The thick carbonate sequences form major aquifers in the region (Laczniak and others, 1996) although, in the study area, basement gravity (Hildenbrand and others, 1999) indicates that most of the Precambrian and Paleozoic sedimentary sequences are composed of fine-grained siliceous clastic rock.

In the Great Basin, a period of little deposition lasted for the next 200 million years, ending with widespread volcanism beginning in the eastern part of the Great Basin during Eocene $(\approx 43$ Ma) time (McKee and others, 1970). This major volcanic episode continued through late Oligocene to early Miocene time (31 to $20 \mathrm{Ma}$ ) when more than 35,000 km3 of ash flow deposits were erupted (Best and others, 1989). This volcanic activity initially was concentrated north of the study area but migrated southwestward in middle Miocene time into the area of this study.

Volcanic deposits in the study area comprise what is called the southwestern Nevada volcanic field (SWNVF, Christiansen and others, 1977), where activity began at about $16 \mathrm{Ma}$ following the inception of typical Basin and Range faulting (McKee, 1971). Lava flows and pyroclastic deposits were erupted between about 15 and 14 Ma from a number of vents, whose exact locations are poorly known because they are buried by younger deposits. Units in this group, in order of decreasing age, includes the Redrock Valley Tuff, Tuff of Yucca Flat, Tub Spring Tuff, Tunnel Formation, lava of Tram Ridge, and the Lithic Ridge Tuff. The oldest caldera that has been identified in the area is the Grouse Canyon caldera (part of the Silent Canyon caldera complex, fig. 3), thought to have resulted from eruption of the Grouse Canyon Tuff at about 13.7 Ma (Sawyer and others, 1994). Individual calderas of the Silent Canyon caldera complex, however, are not recognized in the gravity model of Hildenbrand and others (1999). Hildenbrand and others consider the complex to probably consist of one large caldera that has been modified by a group of partially collapsed calderas. Their suggestion, shown in figure 3 , is accepted in the new geologic map of the region by the U.S. Geological Survey (1999). The Silent Canyon caldera complex is buried by younger deposits, but its location is indicated geophysically by a pronounced gravity low first described by Healey (1968).

Between 12.9 and 12.7 Ma (Sawyer and others, 1994), voluminous eruptions of the Paintbrush Group lava flows and tuff collectively led to the formation of the Claim Canyon caldera (fig. 3) during the late stages of eruption of the Tiva Canyon Tuff (Byers and others, 1976a). Only the southern portion of this caldera remains exposed. Climactic eruptions of the Rainier Mesa (11.6 Ma) and Ammonia Tanks (11.45 Ma) Tuffs (Sawyer and others, 1994), led to the formation of the Rainier Mesa and Ammonia Tanks calderas of the Timber Mountain caldera complex (Byers and others, 1976a). Later (9.4 Ma), and smaller, eruptions of the Thirsty Canyon Group Tuffs (Sawyer and others, 1994) led to the collapse of the Black Mountain caldera. Eruption of the Spearhead and Civet Cat Canyon Members of the Stonewall Flat Tuff formed the youngest (6.3 Ma) caldera of the SWNVF, the Stonewall Mountain caldera (Weiss and Noble, 1989), northwest of the study area. A generalized vertical section of the volcanic sequence in our immediate area is shown in figure 4. 


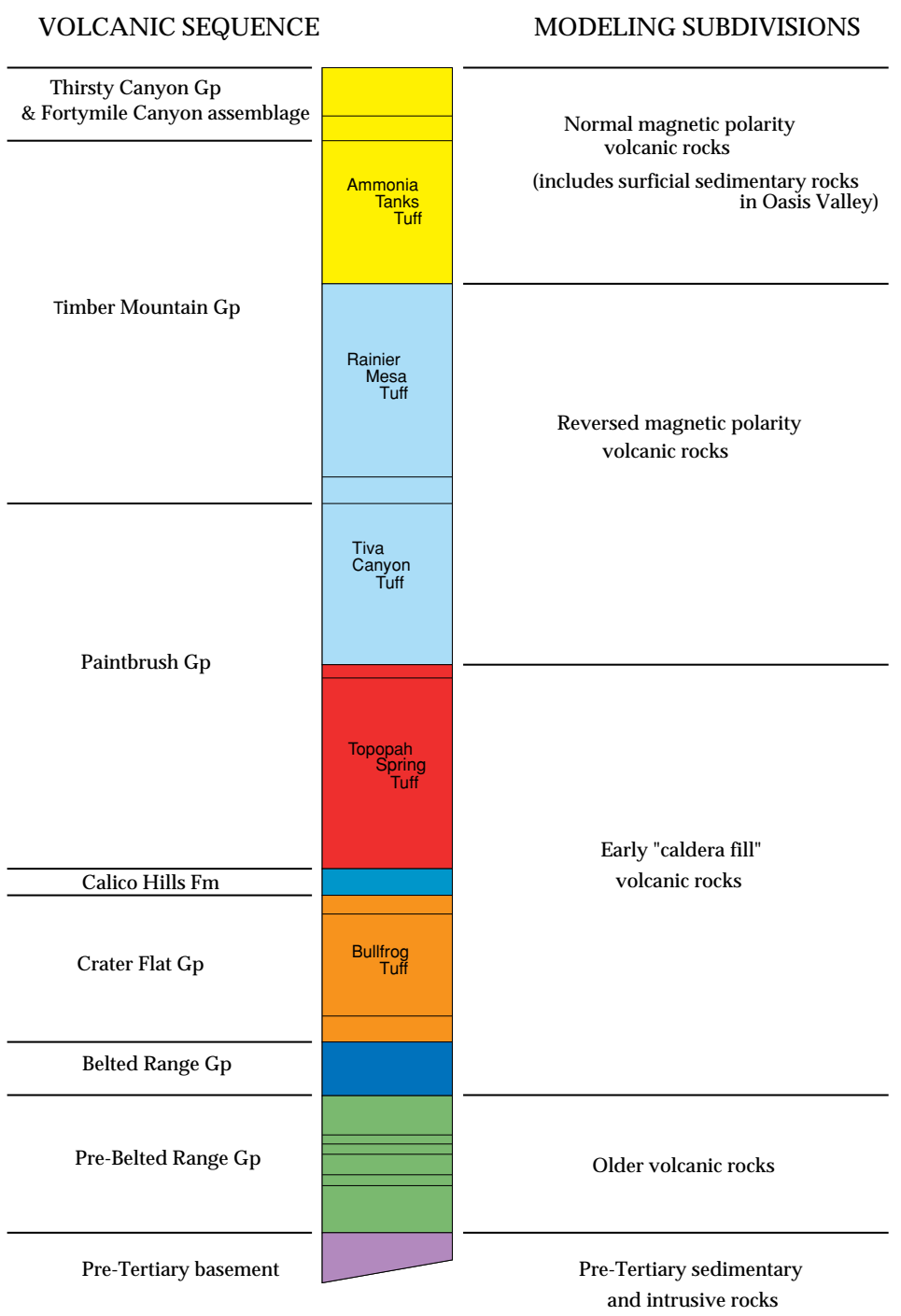

Figure 3. Map showing inferred boundaries of known calderas (U.S. Geological Survey, 1999) in the central Southwest Nevada Volcanic Field (SWNVF). Contour interval is 100 meters. 
The volcanic deposits of the southwestern Nevada volcanic field serve as major aquifers and confining units. Laczniak and others (1996) consider parts of the Rainier Mesa, Tiva Canyon, and Topopah Spring Tuffs, along with volcanic units of the Calico Hills Formation to be major aquifers in Pahute Mesa-Oasis Valley study area. Major confining units include some of the tuffs of the Crater Flat Group (particularly the Bullfrog Tuff), the Tunnel Formation, and some of the older volcanic rocks.

\section{REGIONAL GEOPHYSICAL FEATURES}

A major gravity low centered over the Pahute Mesa - Oasis Valley area has been known since the gravity study of Healey (1968). The magnitude of this low has few counterparts in the western United States (Simpson and others, 1986), and probably is caused by a thick sequence of low-density volcanic rocks within one or more volcanic depressions (calderas). Data from subsequent regional gravity surveys (Grauch and others, 1997, 1999; Ponce, 1997) and the more detailed data provided by this study (Mankinen and others, 1998) enabled us to produce the revised isostatic residual gravity map shown in figure 1 . A number of prominent subsurface features seen on regional gravity maps (Grauch and others, 1999) are expressed as gravity lineaments (Hildenbrand and others, 1999) and shown in figures 2 and 5. We refer to these features by the informal names given in figure 2 .

Aeromagnetic data of McCafferty and Grauch (1997) have been upward continued $100 \mathrm{~m}$ and then subtracted from the original data to produce the residual field. The magnetic anomaly data were reduced to the magnetic pole, a technique that shifts most anomalies to positions more nearly centered over the bodies that cause them. Prominent magnetic lineaments are shown on the residual reduced-to-pole magnetic field map in figure 6 . Because a body with uniform magnetization and density has a magnetic field proportional to the derivative of the gravity field, a gravitational attraction can be derived from the magnetic data (the pseudogravity transform). A magnetic-potential-field map of the study area shown in figure 7 enhances broad and deep changes in crustal magnetic properties. A summary of these and other magnetic techniques can be found in Blakely and Connard (1989), and Blakely (1995).

Often the gravity and aeromagnetic lineaments are nearly coincident. A comparison of these lineaments with caldera boundaries ( figs. 5, 6, and 7) strongly indicates that many of the lineaments are related to caldera formation. The very detailed geophysical model of Pahute Mesa produced by Ferguson and others (1994) reinforces this interpretation. Magnetic lineaments may also reflect other geologic structures such as detachment and extensional faults, accommodation zones, and basement lithologic variations. The high-frequency aeromagnetic data (fig. 6), for example, correlate well with mapped surficial faults, especially on Pahute Mesa. New faults and the extensions of others known previously also are readily apparent. The northeast-trending gravity and magnetic anomalies (the Thirsty Canyon lineament) on Pahute Mesa apparently terminate (figs. 2, 5, 6 and 7) and are replaced by gravity structures trending east-west (Colson Pond, Fleur-De-Lis, and Hot Spring lineaments). Magnetic lineaments parallel the Colson Pond and Hot Spring lineaments based on gravity analysis (fig. 6). However, several prominent, northsouth-trending magnetic anomalies also are present both in the Oasis Valley basin and in the vicinity of the Transvaal Hills on the west side of the Timber Mountain caldera complex (fig. 5). Changes in trend of anomalies south of latitude $37^{\circ} 05^{\prime} \mathrm{N}$ may represent an accommodation zone separating terranes with different structural grains. 


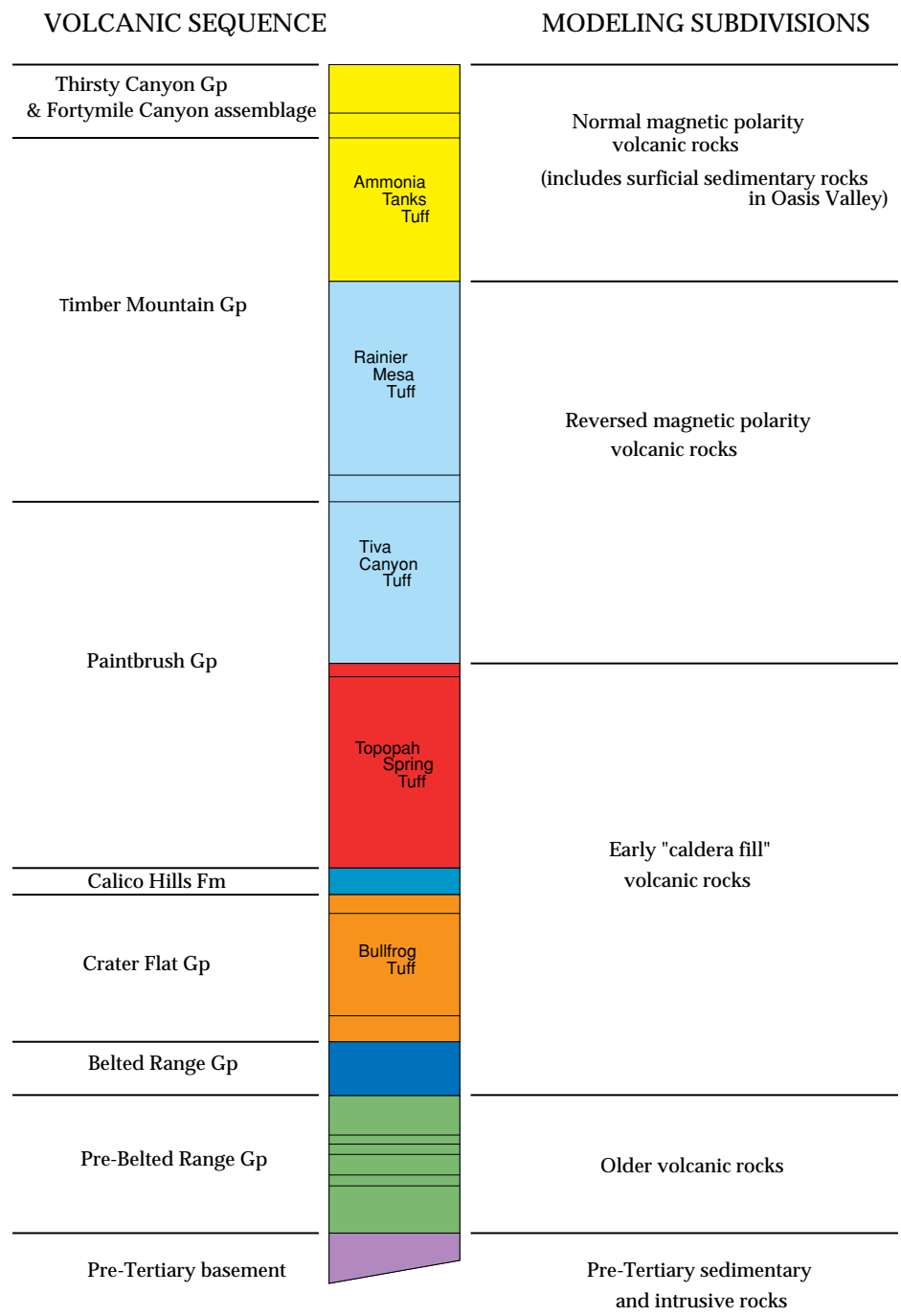

Figure 4. Highly generalized volcanic stratigraphy for the study area. Unit colors are consistent with those shown in our geologic interpretations. Horizontal lines in the column denote unit boundaries within the larger volcanic groups. Only the names of the most prominent units are shown on the column. Unit thickness schematically depicts the erupted magma volumes as estimated by Sawyer and others (1994). 


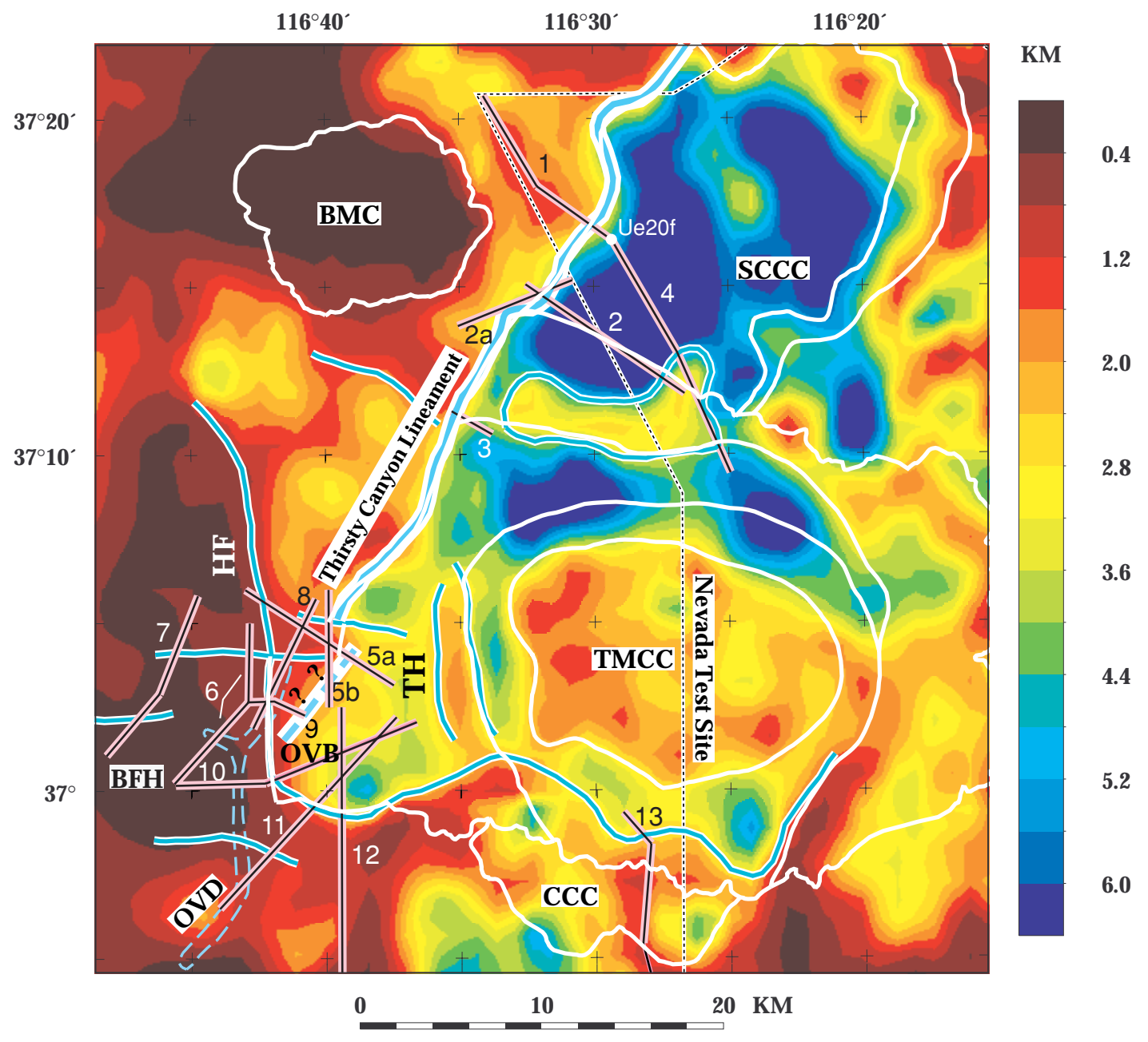

Figure 5. Thickness of Cenozoic volcanic rocks and sedimentary deposits based on the inversion of gravity data and constrained by well data (from Hildenbrand and others, 1999). Magenta lines show location of detailed gravity profiles (numbers from text and fig. 2). Heavy white/blue lines delineate inferred density boundaries. Solid white lines are caldera boundaries from the U.S. Geological Survey (1999). BFH, Bullfrog Hills; BMC, Black Mountain caldera; CCC, Claim Canyon caldera; HF, Hogback fault; OVB, Oasis Valley basin; OVD, Oasis Valley discharge area; SCCC, Silent Canyon caldera complex; TH, Transvaal Hills; TMCC, Timber Mountain caldera complex. 


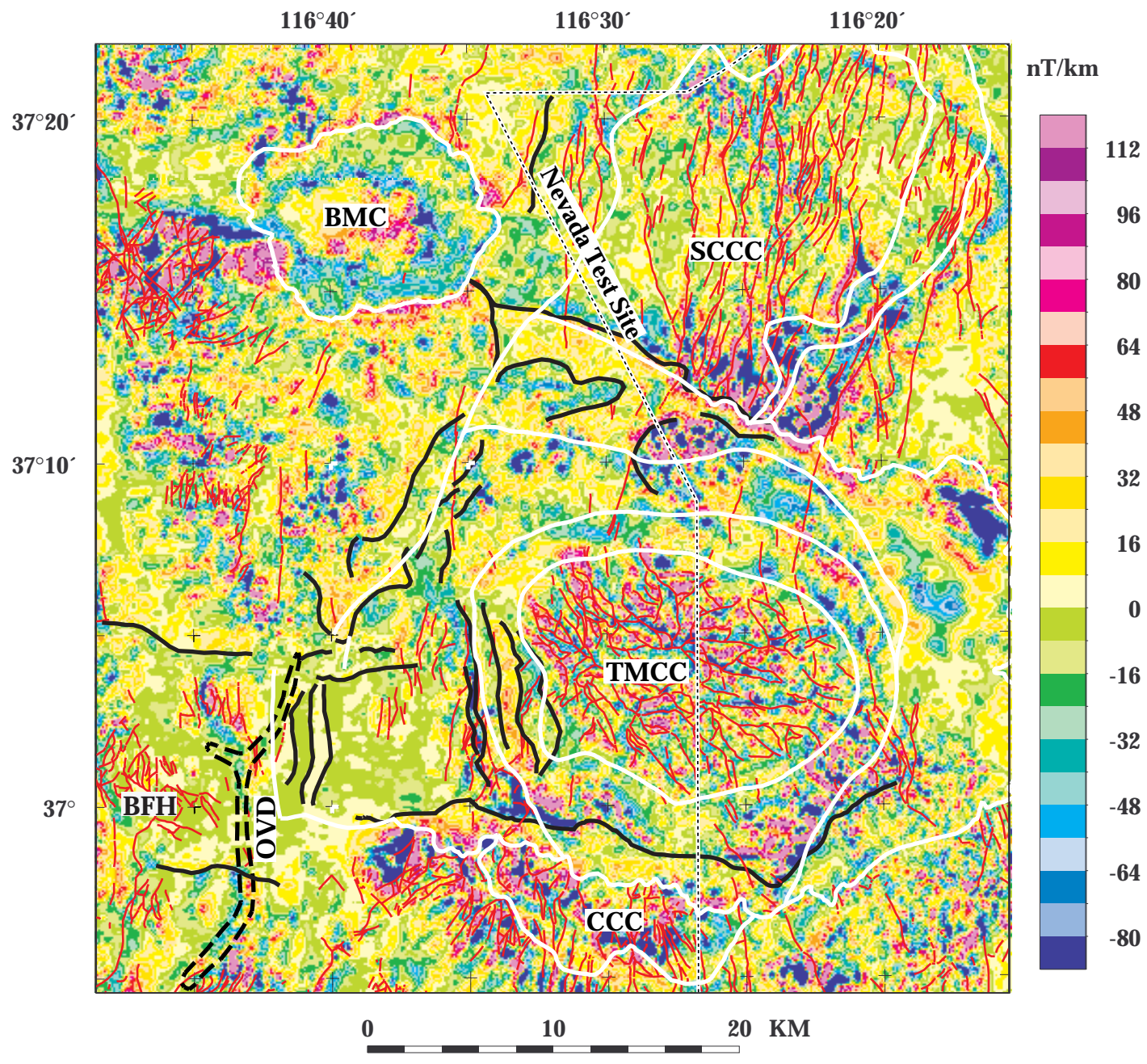

Figure 6. Residual reduced-to-pole magnetic field. The magnetic field was upward continued $100 \mathrm{~m}$ and then subtracted from the original data to produce the residual field. Anomalies enhance the expression of near-surface magnetic sources. Heavy black lines are inferred major magnetic boundaries in the area between Pahute Mesa and Oasis Valley. Red lines are mapped faults (Wahl and others, 1997). See figure 5 for additional explanation. 


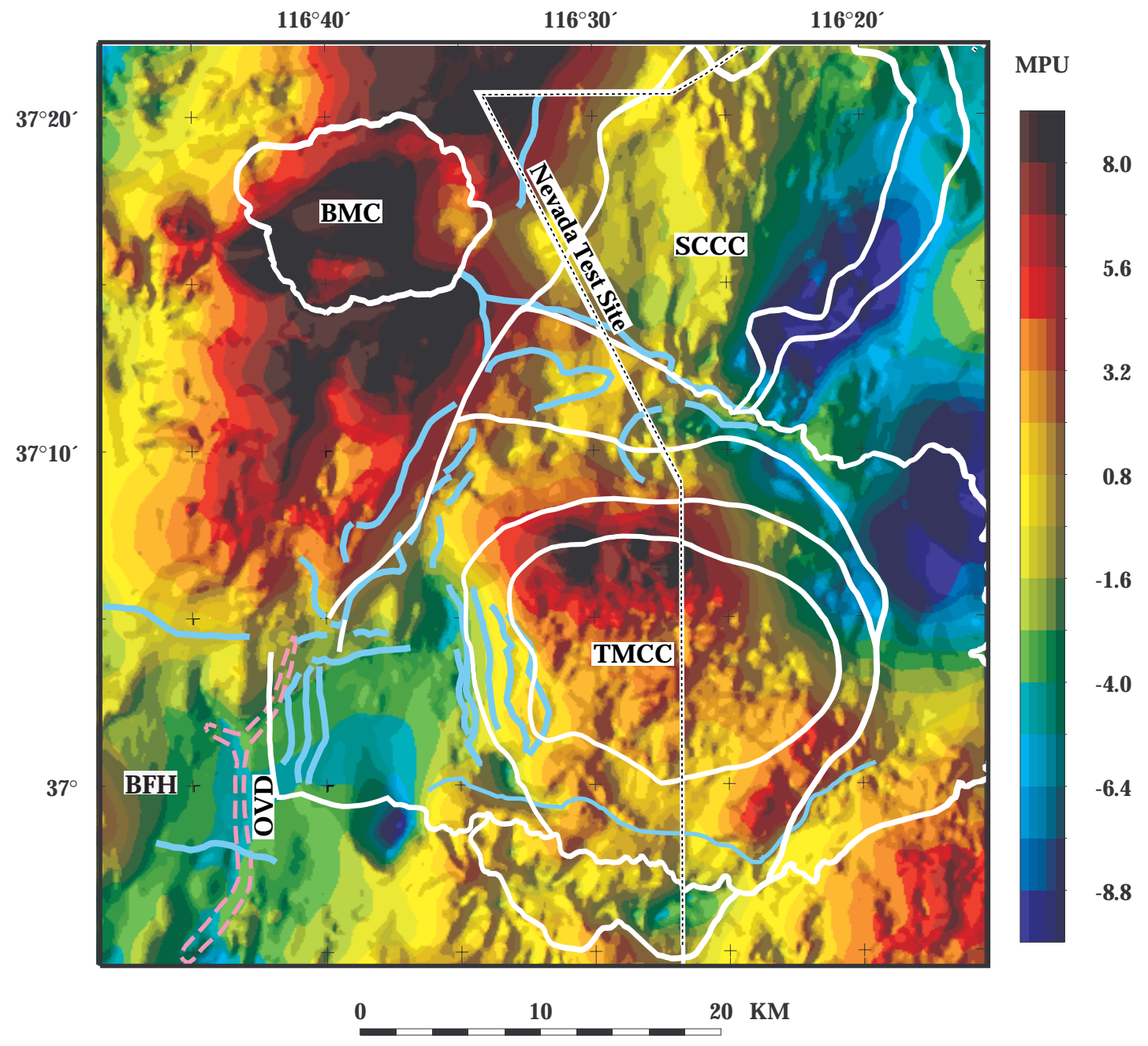

Figure 7. Magnetic potential field. Units are arbitrary magnetic potential units (mpu), dimensionally amperes. The magnetic potential field conveys information concerning regional variations of bulk magnetic properties. Heavy cyan lines are inferred major magnetic boundaries in the area between Pahute Mesa and Oasis Valley. See figures 5 and 6 for additional explanation.

The Thirsty Canyon lineament (fig. 2) is expressed by a very prominent, at least $35-\mathrm{km}$ long, northeast-trending linear gravity feature that also appears partly on aeromagnetic maps. Although this lineament is coincident with several inferred caldera boundaries, its pronounced linearity raises the possibility that a pre-caldera structure is represented (Grauch and others, 1997). Hildenbrand and others (1999) propose that the structure may represent a pre-existing fault zone that might have influenced caldera development.

\section{GEOPHYSICAL DATA}

In order to characterize the geometry and depth of these regional structures (as well as their trend and extent), we established a number of closely-spaced $(100 \mathrm{~m})$ gravity stations along 
profiles that cross perpendicularly the previously identified features. Procedures used in the field and for reducing the gravity data were described by Mankinen and others (1998). Gravity stations were established along profiles crossing several major features (figs. 2 and 5) seen on the regional gravity and magnetic maps. Precise locations of our gravity stations were determined using a differential global positioning system (GPS) and probably are accurate to within about $0.3 \mathrm{~m}$ (Mankinen and others, 1998). Relative elevations within a particular profile are accurate to about $0.03 \mathrm{~m}$. With precise elevation control and subdued topography near most of our gravity profiles, Bouguer anomaly values generally are accurate to within $0.1 \mathrm{mGal}$.

\section{Density Distribution}

In order to model structures that may be responsible for gravity features in the study area, we select representative densities of the Tertiary deposits filling the basin that underly the Pahute Mesa - Oasis Valley area. These estimated densities are then inverted to determine the geometries of subsurface structures. Density information was obtained by examining gamma-gamma density logs available for four drill cores (PM-2, PM-3, UE20j, and UE20f) on Pahute Mesa, from borehole gravity studies available for numerous wells throughout the area (Phelps and others, 1998; Hildenbrand and others, 1999), and through review of published geologic, hydrologic, and geophysical reports of the region.

The basin-fill rocks are almost entirely of volcanic origin, along with some sedimentary units occurring primarily in the Oasis Valley area. The section consists of basalt to rhyolite lava flows, both welded and unwelded ash-flow tuffs, shallow intrusions, sedimentary interbeds, and brecciated material. Ash-fall deposits, both primary and water-lain, are present in significant amounts and represent some of the lowest-density rock types within the basins. Although individual volcanic units can be relatively dense, the average density from ground level to depths of tens or hundreds of meters can be lowered considerably because of landslide and shallow lake deposits, especially within calderas. Significant variations in density also occur in the ash-flow tuffs due to the degree of welding and alteration. Density, in general, will increase with increasing water content, degree of welding, and increasing depth of burial.

\section{Unsaturated Rocks}

The first density interval considered is that part of the section lying above the water table, or above the zone of pervasive zeolitization which generally begins near the top of saturated rock in Pahute Mesa (Carroll, 1989; Schenkel and others 1999). Included are Quaternary volcanic rocks, sedimentary deposits, and late Tertiary volcanic rocks of the Thirsty Canyon Group, the Volcanics of Fortymile Canyon, and most of the Timber Mountain Group. Density of sediment (alluvium) ranges between 1600 and $2000 \mathrm{~kg} / \mathrm{m} 3$ (Snyder and Carr, 1984). Densities within the volcanic section range between 1700 and $2300 \mathrm{~kg} / \mathrm{m} 3$ (Snyder and Carr, 1984),

and between 1400 and $2500 \mathrm{~kg} / \mathrm{m}^{3}$ (Ferguson and others, 1994). These large density variations in the volcanic section result from extensive landslide breccia, debris from rock avalanches, alluvial fan deposits, and colluvium which exceeds a few hundred meters in thickness for all volcanic groups (see summary by Minor and others, 1993). Groups of similar density were averaged for 17 well $\operatorname{logs}$ from Rainier Mesa (Carroll, 1989). An average density of $1750 \mathrm{~kg} / \mathrm{m}^{3}$ was determined for rocks above the pervasive zeolitization zone. Bulk overburden densities in 42 wells from NTS Area 20 (R.G. Warren, Los Alamos National Laboratory, written commun. 1998; URL http://queeg.ngdc.noaa.gov/seg/geochem/swnvf/) averaged $1920 \mathrm{~kg} / \mathrm{m}^{3}$. A density of $1900 \mathrm{~kg} / \mathrm{m}^{3}$ is considered a reasonable estimate of the average density in the uppermost part of the stratigraphic sequence.

Complicating this simple model, however, is the fact that the water table on Pahute Mesa is at a depth of approximately $600 \mathrm{~m}$. At these deeper levels, density should increase significantly according to density estimates by Healey (1968) and Snyder and Carr (1984). Indeed, the density 
of the Rainier Mesa Tuff, which is the oldest unit immediately above the water table in three of the reference drill holes (the unit is not present in PM-2), ranges from 1900 to $2200 \mathrm{~kg} / \mathrm{m}^{3}$. The Rainier Mesa Tuff is exposed over a wide area and has thicknesses ranging from $150 \mathrm{~m}$ (outflow sheet) to more than $500 \mathrm{~m}$ (intracaldera and ponded localities). Because this unit has a distinctive density and magnetic signature (discussed below) that differs from the rocks above, a separate subdivision for these unsaturated rocks is warranted. Ferguson and others (1994) also consider the Rainier Mesa Tuff to be a major density unit that averages $2150 \mathrm{~kg} / \mathrm{m}^{3}$. Based on available information, $2100 \mathrm{~kg} / \mathrm{m}^{3}$ is considered to be a reasonable estimate of the density of this unit. The change in density from 1900 to $2100 \mathrm{~kg} / \mathrm{m}^{3}$ commonly occurs at depths between $200-300 \mathrm{~m}$.

\section{Saturated Rocks}

Rocks below the water table are expected to be denser than rocks at higher stratigraphic level due, at least in part, by increasing saturation and zeolitization. The density increase is on the order of a few percent. Combining data from 5 surface samples of the Rainier Mesa and Tiva Canyon Tuffs for which both unsaturated and saturated densities are reported (Snyder and Carr, 1984, their Table 2), density increases from 2120 (unsaturated) to $2270 \mathrm{~kg} / \mathrm{m}^{3}$ (saturated). Rocks most commonly exposed near the top of the saturated zone belong to the Paintbrush Group, the Calico Hills Formation, the Crater Flat Group, and the Belted Range Group. The limited density data from these units in the four reference drill holes range from about 2100 to $2300 \mathrm{~kg} / \mathrm{m}^{3}$ except at the deepest levels. Snyder and Carr (1984) report an average density of $2260 \mathrm{~kg} / \mathrm{m}^{3}$ (saturated) for 70 samples of the rhyolite of Calico Hills. Thus, a density of $2300 \mathrm{~kg} / \mathrm{m}^{3}$ is considered a reasonable estimate for rocks occurring at depths between about $600 \mathrm{~m}$ and $1,200 \mathrm{~m}$.

The oldest Tertiary rocks in the area are comprised of the Volcanics of Quartz Mountain, the Dacite of Mount Helen, the Volcanics of Big Dome (Tub Spring Tuff), and the Volcanics of Oak Spring Butte. Of our four reference wells, density information for these older units is available only in PM-2. Here we find an average density of $2200 \mathrm{~kg} / \mathrm{m}^{3}$ at depths shallower than 1 $\mathrm{km}$ (in excellent agreement with our estimate above) and $2430 \mathrm{~kg} / \mathrm{m}^{3}$ between 1 and $1.2 \mathrm{~km}$. Jachens and Moring's (1990) layered density model shows an average density of 2420 below 1.2 $\mathrm{km}$ depth for the state of Nevada. For our purposes, we will consider a density of $2450 \mathrm{~kg} / \mathrm{m}^{3}$ to be representative of these older volcanics. Borehole gravity measurements (Hildenbrand and others, 1999, figure 5) also are indicative of $2450 \mathrm{~kg} / \mathrm{m}^{3}$ densities below $1.2 \mathrm{~km}$.

The last density that needs to be determined is for the pre-Tertiary basement rocks. For this region, saturated densities determined for Precambrian quartzite, Paleozoic and Mesozoic argillite and carbonate average $2660 \mathrm{~kg} / \mathrm{m}^{3}$ (Snyder and Carr, 1984). Ferguson and others (1994) assign a density of $2650 \mathrm{~kg} / \mathrm{m}^{3}$ for these basement rocks. We assume a density of $2670 \mathrm{~kg} / \mathrm{m}^{3}$ for the preTertiary basement rocks, which is a commonly-used reduction density in geophysical studies (see, for example, Simpson and Jachens, 1989).

Because these density measurements were made on samples from various drill holes and surface outcrops within the study area and surrounding region, this density distribution model should be widely applicable. Below about $200 \mathrm{~m}$, our density distribution model is very similar to that derived by Jachens and Moring (1990) for volcanic deposits throughout the state of Nevada. Pahute Mesa, however, seems to be anomalous. Borehole gravimeter studies (R.G. Warren, LANL, written commun., 1998) show low-density material $\left(2100 \mathrm{~kg} / \mathrm{m}^{3}\right.$ and less) extending to depths greater than $1 \mathrm{~km}$. Hildenbrand and others (1999) indicate that by taking into account deeper low-density volcanic rocks, the average estimated basement in the Pahute Mesa area will be about $1.5 \mathrm{~km}$ shallower than that shown in figure 5. The profiles shown in this paper have been adjusted to account for the shallower basement. 


\section{Magnetic Property Data}

Magnetic data for the same profiles were derived from available aeromagnetic data (McCafferty and Grauch, 1997). Because the aeromagnetic data were obtained from many sources of variable quality and type, McCafferty and Grauch produced a merged aeromagnetic-anomaly map that is a representation of the data as if all surveys were flown at a constant elevation (reduction datum level $=122 \mathrm{~m}$ above terrain). Some of the older aeromagnetic surveys were flown at a flight-line spacing of $1600 \mathrm{~m}$, whereas the more recent, detailed surveys were flown at $800 \mathrm{~m}$ or less (McCafferty and Grauch, 1997). These aeromagnetic data are used to further constrain and enhance the geophysical models.

Paleomagnetic directions and total magnetizations of the volcanic rocks in the study area are needed for the interpretation of aeromagnetic anomalies. We need to consider, mainly, a representative value for the magnetic polarity of composite rock sequences (defined below) underlying the aeromagnetic survey rather than the magnetization direction of individual units. When the magnetization direction of rocks spanning an appreciable length of time (on the order of $10^{4}$ years) are averaged, their mean direction will correspond to one produced by a geocentric axial dipole field. In rocks as young as these, the expected direction is that of the ambient field.

Hudson and others (1994), however, have documented a small $\left(7.1^{\circ} \pm 6.6^{\circ}\right)$, but significant, amount of post-middle Miocene, counter-clockwise, vertical-axis rotation of the central SWNVF with respect to the North American craton. The angular distance between this rotated remanent magnetization direction and the ambient field used here $\left(\mathrm{I}=60^{\circ}, \mathrm{D}=010^{\circ}\right)$ is roughly $12^{\circ}$ and unlikely to have an appreciable effect on the results.

Total magnetizations are much more difficult to characterize than remanent magnetization directions. Intensity of magnetization may vary widely within a volcanic unit, both laterally and vertically (see, for example, Rosenbaum, 1993), as well as between units because of variations in magnetic grain size and concentration of magnetic minerals. For volcanic rocks in the study area, magnetizations commonly range between 0.1 to $1 \mathrm{~A} / \mathrm{m}$, although it is not unusual for specific units to have magnetization intensities well outside this range. Representative magnetizations can be found in Bath (1968), Rosenbaum and Snyder (1985), Ponce and Langenheim (1995), and Grauch and others $(1997,1999)$. In our modeling approach, we assumed initially that all the volcanic rocks have the same intensity of magnetization with the exception of the Rainier Mesa Tuff which is generally more magnetic (M.R. Hudson, U.S. Geological Survey, personal commun., 1998). Surficial sediment is weakly magnetized ( $\mathrm{M}=0 \mathrm{~A} / \mathrm{m})$ and has no effect on the aeromagnetic anomalies. While the pre-Tertiary basement consists mainly of weakly magnetized clastic sedimentary rocks, abundant granitic dikes, sills and other intrusions associated with the voluminous volcanism also are expected. Although intrusive rocks have stronger magnetizations than sediment, they generally will have a negligible effect on the aeromagnetic anomaly because of their depth of burial. Here, again, we assume $\mathrm{M}=0 \mathrm{~A} / \mathrm{m}$ for modeling purposes.

\section{GEOPHYSICAL MODELS}

\section{Description of Units}

We modify slightly the subdivisions given in the previous section to use all pertinent physical properties available. These properties are summarized in table 1. Units within the study area that have distinctly identifiable physical properties are (listed from the surface to basement):

(1). Surficial sediment. This unit consists of the Oasis Valley gravels and various undifferentiated sedimentary deposits that are mostly of Quaternary age. Although densities are comparable with those of the underlying volcanic sequence, sediment contains a magnetization that is too weak to be detected by aeromagnetic surveys. 
(2). "Normal" volcanics. Predominately normal magnetic polarity volcanic rocks with a moderate to strong magnetic intensity. The unit includes the youngest Tertiary volcanic rocks, the Thirsty Canyon Group, the Volcanics of Fortymile Canyon, and the uppermost member of the Timber Mountain Group (the Ammonia Tanks Tuff). Some reversed polarity volcanic rocks are present (Grauch and others, 1997, 1999) but these are volumetrically small, of limited areal extent, and will have little effect on the aeromagnetic anomalies, except perhaps on a local scale.

(3). "Reversed" volcanics. Moderately to strongly magnetized, reversed magnetic polarity volcanic rocks, primarily the Rainier Mesa Tuff member of the Timber Mountain Group. The unit also includes the upper members of the Paintbrush Group (post-Tiva Canyon rhyolite and the Tiva Canyon Tuff). These members contain a strong, reversed polarity magnetization. Average densities for 12 samples of the Tiva Canyon Tuff (Langenheim and others, 1993) are $2080 \mathrm{~kg} / \mathrm{m}^{3}$ (unsaturated) and $2130 \mathrm{~kg} / \mathrm{m}^{3}$ (saturated), comparable to those determined for the Rainier Mesa Tuff as described in the previous section.

(4). Early "caldera-fill" volcanics. This unit includes the Topopah Spring Tuff of the Paintbrush Group, and those volcanic rocks that erupted to form the Claim Canyon caldera and the Silent Canyon caldera complex. Magnetic polarity is predominately normal, but intensities generally range from weak to moderate. Here, again, some reversed polarity volcanic rocks occur (Grauch and others, 1997, 1999), but the volumetrically important rocks including the Topopah Spring Tuff, the Calico Hills Formation, the Bullfrog Tuff, and the Deadhorse Flat Formation, mostly consist of rocks with normal magnetic polarity.

(5). "Older" volcanics. Pre-Belted Range Group (15 to $14 \mathrm{Ma}$ ), consisting of both normal and reversed polarities. Magnetizations are weak to moderate. Because of a significantly weaker magnetization intensity than in the overlying volcanic rocks and because, under normal circumstances, they occur at depths greater than $1.2 \mathrm{~km}$, the older volcanics have little effect on the aeromagnetic anomalies. For modeling purposes, we assume that the total assemblage averages to a normal magnetic polarity. Densities are higher than for other volcanic sequences in the area mainly because of deep burial.

(6). Pre-Tertiary "basement." Precambrian, Paleozoic, and Mesozoic rocks of varying lithologies. Both normal and reversed polarities are present but magnetizations generally are weak because sedimentary rocks are predominant, and because depth of burial often has altered the magnetic mineralogy. One exception is the argillite member of the Paleozoic Eleana Formation, which has a magnetization as strong as any of the overlying volcanic rocks (Bath and Jahren, 1984). If this formation is present in areas of shallow basement, it will have a significant effect on the aeromagnetic anomalies. 
TABLE 1. Density and magnetization of rocks from the Pahute Mesa - Oasis Valley region

$\underline{\text { Physical subdivisions }}$

Unit \#1: Sediment (unnamed Quaternary sediment and Oasis Valley gravels)

Unit \#2: "Normal" magnetic polarity volcanics. (Ammonia Tanks Tuff, Volcanics of Fortymile Canyon, Thirsty Canyon Group, and younger volcanic rocks)
Unit \#3: "Reversed" magnetic polarity volcanics. (Tiva Canyon and Rainier Mesa Tuffs)

$\frac{\text { Density }}{\left(\mathrm{kg} / \mathrm{m}^{3}\right)} \frac{\text { Magnetization }}{(\mathrm{A} / \mathrm{m})}$

1900

1900

0.5

2100

0.8

2300

earliest caldera-forming events. (Silent Canyon caldera complex)

Unit \#5: “Older” volcanics. Pre-Belted Range Group, early Tertiary volcanic rocks. (Volcanics of Quartz Mtn, Volcanics of Oak Spring Butte, Volcanics of Big Dome, Dacite of Mount Helen)

Unit \#6: "Pre-Tertiary" basement. Precambrian, Paleozoic, and Mesozoic argillite, carbonate rock, and quartzite.

The 6 basic units used in developing the geophysical models are given in table 1 and shown in figure 4. Formation/unit names in parentheses are those commonly comprising each of the density-magnetic subdivisions. Some deviation from this generalized sequence can be expected because of depth of burial and other reasons detailed above. Density contrasts between units will significantly influence interpretation of the gravity anomalies. The strongly magnetic "normal" and "reversed" volcanics will produce major aeromagnetic anomalies, whereas deeper and more weakly magnetized units will have a minimal effect on the magnetic field. This subdivision represents a highly simplified view of the geology and serves as a starting point for model development. Density, magnetization, thickness and depth of burial often vary within each unit. For example, large lateral variations might be expected for the units depending on whether they are found inside or outside the caldera complexes.

\section{Modeling Approach}

Observed gravity and magnetic anomalies were used to construct initial geologic models of the subsurface using a commercially-available 2 1/2-dimensional modeling program ("GMSYS") based on Webring (1985). The program requires an initial estimate of model parameters (table 1), and varies them to reduce the weighted root-mean-square error between observed and calculated gravity and magnetic values along the profile. However, the solutions obtained are not unique because an infinite number of geometric models will have an associated field that closely matches the measured field. To constrain the models, we use the simultaneous inversion of gravity and magnetic data together with available drill hole information, published geologic reports, maps and interpretive cross-sections, a map of basin thickness (Hildenbrand and others, 1999), and density/depth variations (discussed previously). Where possible, our profiles crossed several wells (PM-2, PM-3, UE20j, UE20f, Coffer) or were extrapolated to gravity stations established on 
pre-Tertiary rock outcrops to provide additional constraints. If assumed densities and

magnetizations are representative, the resulting geophysical models should reasonably approximate actual geologic structure.

\section{RESULTS}

\section{Thirsty Canyon Lineament}

The NE-trending Thirsty Canyon lineament (TCL) is one of the major features that have been identified on regional gravity and aeromagnetic maps. These major lineaments are shown in figures 2 and 5. The TCL was called the "NNE structure" by Grauch and others $(1997,1999)$.

The Thirsty Canyon lineament (fig. 2) clearly extends at least $35 \mathrm{~km}$ from latitude $37^{\circ} 21^{\prime} \mathrm{N}$ on Pahute Mesa southward toward Colson Pond near the mouth of Thirsty Canyon. Whether or not the lineament extends southwest of Colson Pond is not clear from the available data. Gravity (fig. 5) and aeromagnetic anomalies (fig. 6) are colinear along the southwest section of the Thirsty Canyon but diverge on Pahute Mesa, where the aeromagnetic anomalies strike more northerly above latitude $37^{\circ} 12^{\prime} \mathrm{N}$.

Five detailed profiles (figs 2 and 5) cross the Thirsty Canyon lineament, four on Pahute Mesa (profiles 1, 2, 2a, and 3) and one at the head of Oasis Valley (profile 5a). Profile 1 includes MT lines 1 and 2 of Schenkel and others (1999). Profile $2 \mathrm{a}$ is at an oblique angle to the TCL and follows line 2 of Schenkel and others (1999). Profile 5a (also Schenkel and others' line 4) was sited at the mouth of Thirsty Canyon where the continuation of the Thirsty Canyon lineament is unclear. The lineament might simply terminate along the structures expressed by EW-trending magnetic and gravity gradients at about latitude $37^{\circ} 05^{\prime} \mathrm{N}$ (figs. 2, 5 and 6). Alternatively, the source of the TCL

may actually continue on trend but be masked by the deposits overlying a detachment fault (C.J. Fridrich, unpublished data, 1999). A third possibility is that the TCL is offset approximately $1 \mathrm{~km}$ northeast of profile 5a by left-lateral movement (about $2 \mathrm{~km}$ ) of the anomaly and that it continues southwestward from there to the NS-trending Hogback lineament (fig. 2).

Profile 1 is well constrained with respect to magnetic properties and known lithologies. It begins at well PM-2 on the northwest end of the profile, crosses well UE20j, and ends at well UE20f. Figure 8 shows a model of profile 1 that satisfies the constraints established and adequately accounts for the observed gravity and magnetic data. There is a distinct near-vertical offset (downthrow $\approx 1.5 \mathrm{~km}$ to the SE) at the Thirsty Canyon lineament as it is defined on the anomaly maps. MT continuous-profile Line 1 (Schenkel and others, 1999) indicates a faultbounded vertical conductive zone at the same locality. There also is a similar feature approximately $2.5 \mathrm{~km}$ to the northwest. The strong magnetic anomaly beginning between holes PM-2 and UE20j seems to correspond closely to the northwestern-most extent of the reversed magnetic polarity Rainier Mesa and Tiva Canyon Tuffs. Indeed, the reversed polarity unit is not represented in well PM-2.

In addition to the absence of reversed polarity units, the normal polarity rocks on the northwest part of profile 1 also must be more strongly magnetized than they are to the southeast in order to account for the magnitude of the magnetic anomaly. Grauch and others $(1997,1999)$ considered the sources of this northwestern magnetic high to be the commendite of Ribbon Cliff (part of unit \#1 in table 1), and the tuff of Tolicha Peak and the dacite of Mount Helen (parts of unit \#5, table 1). Although only the dacite of Mount Helen was reported in well PM-2, all three probably underly much of the area of the magnetic high. In the model shown in figure 8 , the magnetization of unit \#1 has been increased from $0.8 \mathrm{~A} / \mathrm{m}$ near the southeast part of profile 1 to 1.2 $\mathrm{A} / \mathrm{m}$ near the northwestern magnetic high. 
Geophysical models perpendicular to the Thirsty Canyon lineament are shown in figure 9. This figure shows only the portion of each profile (figs. 2 and 5) in the proximity of the TCL. Models for all profiles are shown in their entirety in the appendix. Profile 2 (fig. $9 \mathrm{~b}$ ) shows two subparallel structures similar to those in profile 1 (fig 9a) near the inferred position of the TCL.

Both structures, again, indicate moderate- to high-angle offsets. The abrupt change in observed density along profile 3 (fig. 9c) indicates that the offset must be essentially vertical.

Gravity profile 5a (Figure 9d) indicates that the Thirsty Canyon lineament was not crossed or its expression is too subdued to be detected. The TCL may have been offset toward the east and then continue in a southwest direction as shown by the heavy dashed line in figures 2 and 5. MT line 4 (Schenkel and others, 1999) does, however, appears to detect the TCL where it was expected, and here it is expressed as a 2-km wide conductive zone. The geologic model of Schenkel and others shows that the TCL at this locality is confined to relatively shallow depths, and that the vertical displacements related to the TCL are insufficient to produce a clear gravity anomaly. The observed gravity and magnetic data are best fit by assuming that the Rainier Mesa/Tiva Canyon Tuffs directly overlie the basement immediately southeast of the extension of the TCL. The density of the reversed volcanic rocks increases from 2100 to $2300 \mathrm{~g} / \mathrm{cm} 3$, and then to $2450 \mathrm{~g} / \mathrm{cm} 3$ with increasing depth. Note that profile 5 a crosses the Hogback lineament at an oblique angle (figs. 2 and 5). Here the Hogback lineament seems to be very near the western-most extent of the reversed polarity volcanics.

\section{Hogback Lineament}

The Hogback lineament is a prominent north-south-trending gravity feature (fig. 2) that coincides, at least in part, with the scarp of a major normal fault along the eastern side of the Oasis Mountain Hogback (C.J. Fridrich, unpublished data, 1999). The Hogback fault defines the eastern boundary of a single structural block (northeastern Bullfrog Hills domain). This feature was termed the "N-S structure" by Grauch and others (1997, 1999). Profiles 5a, 9, and 10 cross the Hogback lineament. Profile 10 (fig. 10) has been extended to the west to include a surface outcrop of pre-Tertiary basement. The Hogback fault at this locality seems to represent a moderate, northeast-dipping surface. At profile 10, as at profile 5a, the reversed polarity lavas are very thin or absent west of the Hogback fault. This interpretation agrees with recent geologic mapping that indicates that the Hogback fault initially formed before emplacement of the Rainier Mesa Tuff.

\section{Basement Ridge}

The "amoeba-shaped" gravity anomaly located between the Silent Canyon and Timber Mountain caldera complexes ("basement ridge," fig. 2) is crossed by profile 4. The steep gravity gradients, again, seem to be indicative of high-angle structures (fig. 11). The basin thickness map suggests that high density rocks $(2670 \mathrm{~kg} / \mathrm{m} 3)$ may extend to within about three kilometers of the surface. We, however, interpret this anomaly as expressing a dense intrusion penetrating ring fractures within the structural margin of either the Timber Mountain or Silent Canyon caldera complex. Alternatively, the gravity high may reflect dense moat-filling lava. In either case, basement would lie at depths greater than that shown in figure 5 in the region of this gravity high. The inferred structure seems to have no relationship to the source of what we informally call the Buckboard lineament, defined by a major, northwest to southeast boundary in the aeromagnetic data above latitude $37^{\circ} 10^{\prime} \mathrm{N}$ (figs. 6 and 7). The aeromagnetic anomaly may be an expression of near-surface magnetic sources extending to a topographic wall of the Timber Mountain caldera complex.

\section{Colson Pond Lineament}

The Colson Pond lineament is an east-trending gravity feature normal to the Hogback fault near the northern end of Oasis Valley (fig. 2). Profiles 6, 7, and 8 cross this feature. Profile $5 \mathrm{~b}$ is 
located near the eastern terminus of the lineament, although the magnetic data (fig. 6) suggest that the east-west feature may continue farther east. Profiles 6 and 7 have been extended to include a surface outcrops of the pre-Tertiary basement. The Colson Pond lineament at profile 6 seems to represent a high-angle feature with a small amount of downthrow toward the north (fig. 12). However, the gravity anomaly here is very small $(<5 \mathrm{mGal})$. The observed magnetization, both here and at profile 7 (appendix, p. 51) is best modeled by assuming a strong, normal-polarity magnetization $(2.0 \mathrm{~A} / \mathrm{m})$ for some of the basement rocks. A possible candidate for the strongly magnetized basement rock is argillite of the Eleana Formation (Bath and Jahren, 1984). The Eleana Formation does underlie parts of the study area (Winograd and Thordarson, 1975; Laczniak and others, 1996). Although a relatively thin layer of reversed polarity lavas are indicated in the area south of the Colson Pond lineament, only the Thirsty Canyon Group lavas and younger deposits are indicated in the area to the north of this lineament. 

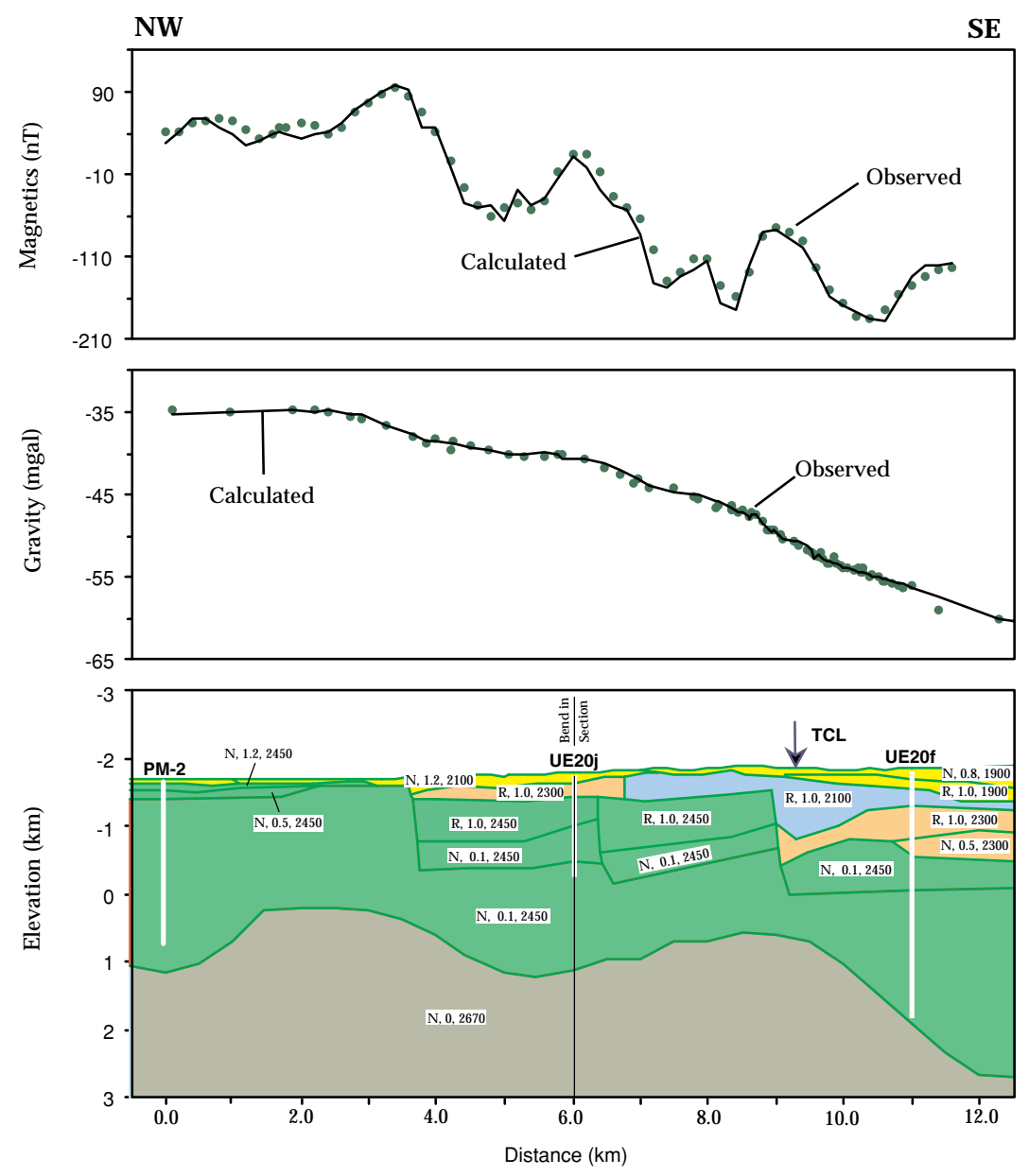

Figure 8. Model (bottom) showing density distribution that will fit the observed gravity (middle) and magnetic (upper) fields along profile 1. Dots are observed gravity and aeromagnetic values along the profile, and the solid curve represents the calculated values based on the model parameters. Also shown are locations of drill holes and the inferred position of the Thirsty Canyon lineament (TCL). Densities are: gray, 2670; green, 2450; tan, 2300; blue, 2100; yellow, 1900 (all in $\mathrm{kg} / \mathrm{m}^{3}$ ). Each block in the model contains a three item descriptor: (1) Magnetic polarity (N, normal; R, reversed), (2) magnetic intensity $(\mathrm{A} / \mathrm{m})$ and, (3) density $\left(\mathrm{kg} / \mathrm{m}^{3}\right)$. Elevations above sea level are expressed as negative numbers. No vertical exaggeration. 


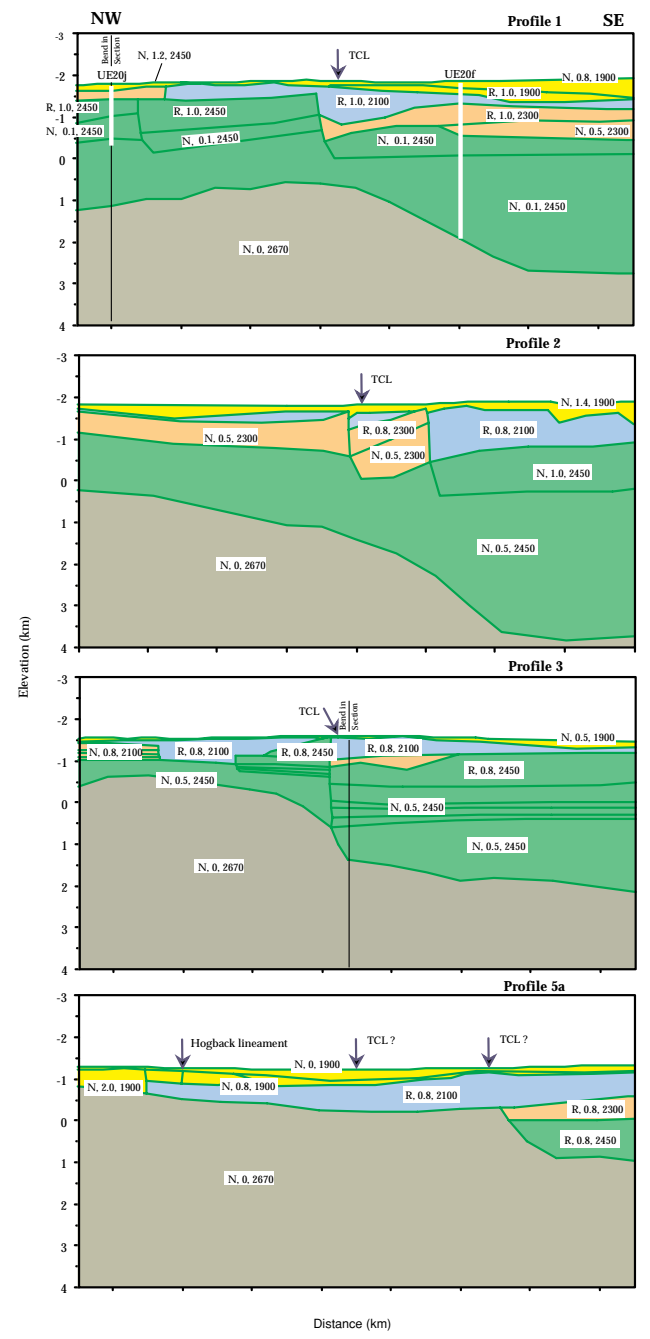

Figure 9. Geophysical models for profiles that cross the Thirsty Canyon lineament (TCL). Vertical exaggeration is 0.6. See figure 8 for additional explanation. 

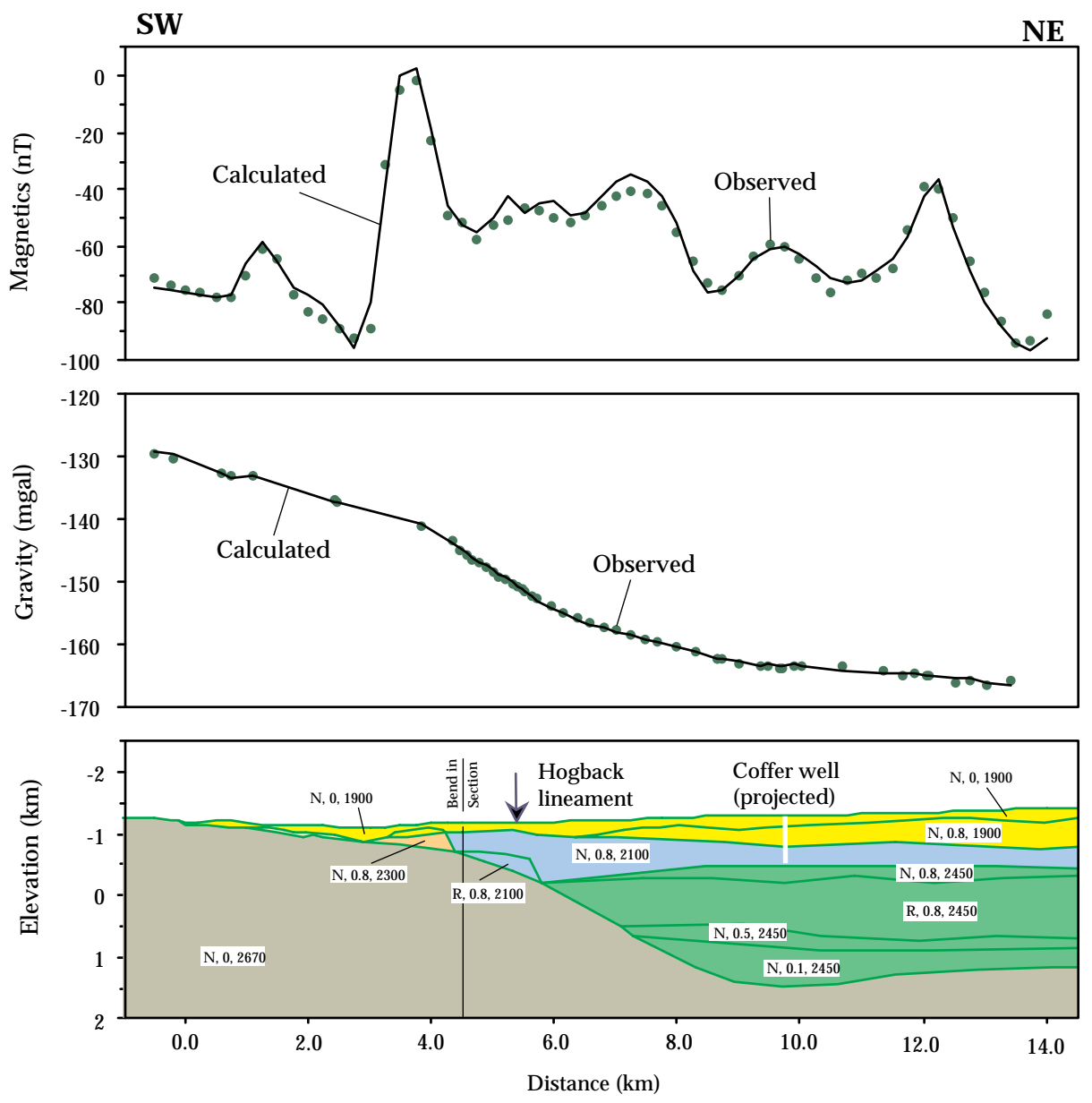

Figure 10. Geophysical model for subsurface structures along profile 10. No vertical exaggeration. See figure 8 for additional explanation. 

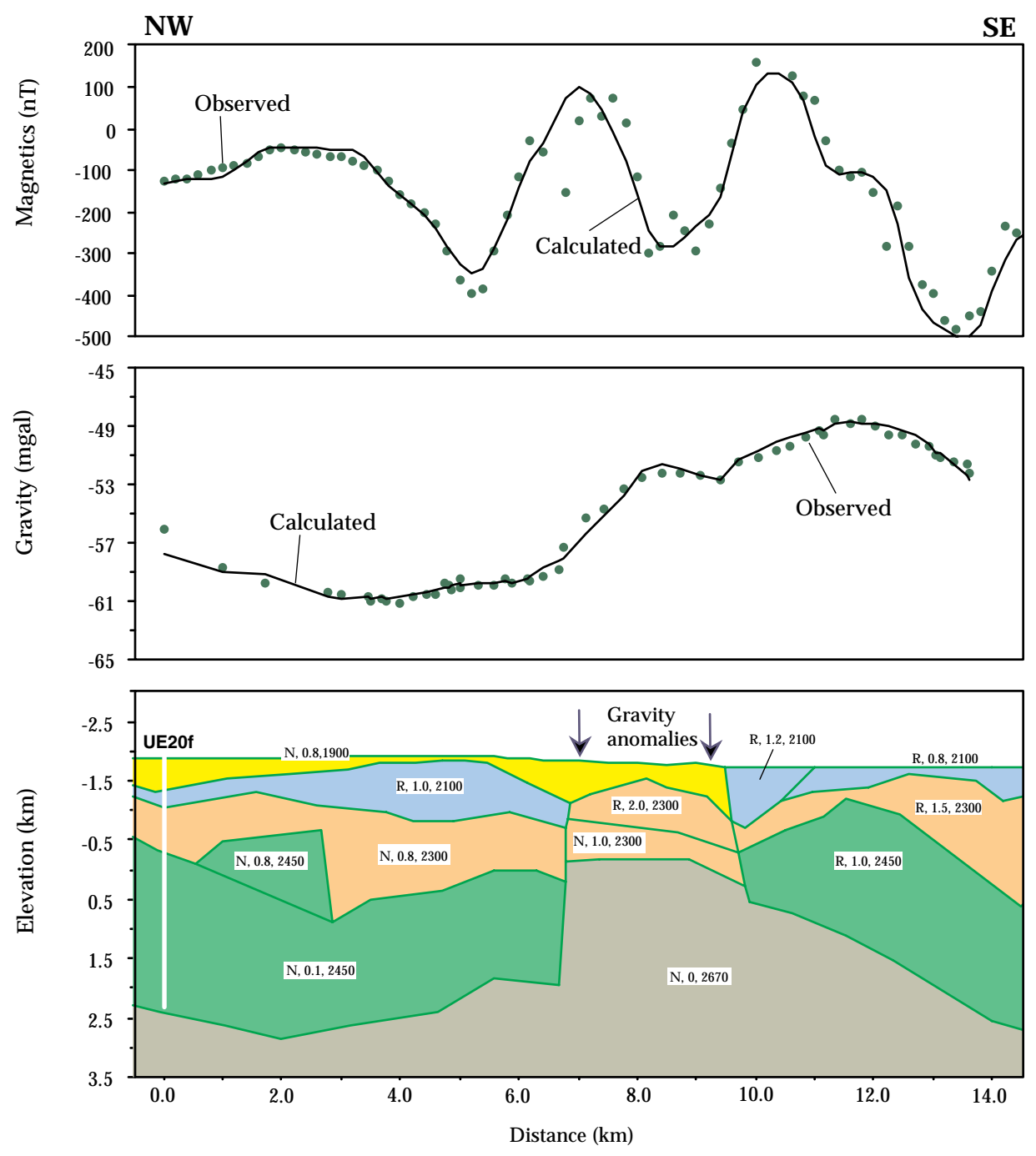

Figure 11. Geophysical model of the subsurface structure along profile 4. No vertical exaggeration. See figure 8 for additional explanation. 

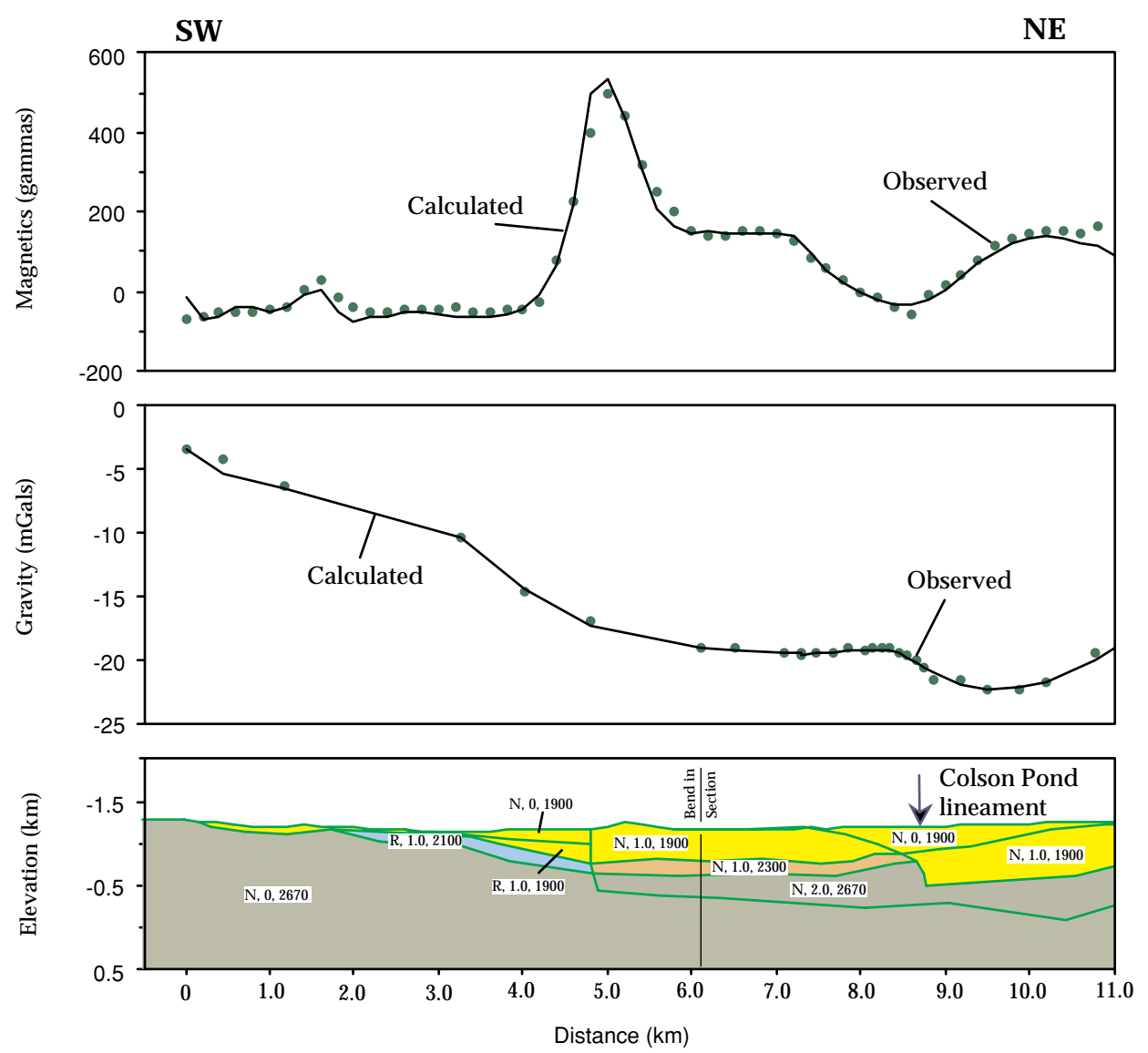

Figure 12. Geophysical model of the subsurface structure along profile 6. No vertical exaggeration. See figure 8 for additional explanation. 


\section{Fleur-De-Lis Lineament}

This lineament parallels, and is approximately $2 \mathrm{~km}$ to the south of, the Colson Pond lineament (fig. 2). Only the extension of profile 7 crosses the feature (appendix, p. 51). Although detailed gravity observations were not acquired, available data suggest that this lineament represents a moderately-dipping structure. Rocks on the northwest side of the Fleur-De-Lis lineament are displaced downward relative to those on the southwest. Only a thin layer of Tertiary rock overlie basement southwest of the lineament. Reversed-polarity volcanics are thin or absent south of this feature.

\section{Hot Springs Lineament}

The Hot Springs lineament occurs near the southern end of the Oasis Valley basin and was called the "E-W structure" by Grauch and others (1997, 1999). The Hot Springs lineament forms the boundary between the northeastern and southeastern Bullfrog Hills domains (C.J. Fridrich, unpublished data, 1999). The western extent of the lineament coincides with a north-dipping bedrock scarp that seems to continue eastward toward the Transvaal Hills where it forms the southwestern structural margin of the Timber Mountain caldera complex (fig. 3). The map of basin thickness (fig. 5), however, indicates that this lineament is not continuous and is separate from the southern end of the Rainier Mesa caldera. The regional magnetic data (figs. 6 and 7) similarly do not delineate a continuous structure extending east from the Hot Springs area. Thus, the eastern terminus of the Hot Springs lineament is assumed here to lie near latitude $36^{\circ} 58^{\prime} \mathrm{N}$, longitude $116^{\circ} 42^{\prime} \mathrm{W}$ (fig. 7). Profile 11 (appendix, p. 55) crosses this lineament near its eastern extent.

\section{Southern Margin of the Oasis Valley Basin}

The southern boundary of the Oasis Valley basin seems to be continuous with, or merges with, the southern structural margin of the Rainier Mesa caldera (fig. 4). Profile 11 (appendix) crosses both the Hot Springs lineament and the southern boundary of Oasis Valley, supporting the above conclusion of two separate structures and not a single continuous structure. The southern boundary of the basin also is crossed by profile 12 (fig. 13). Farther east, profile 13 (fig. 14) crosses the southern structural margins of the Claim Canyon and Rainier Mesa calderas. Both profiles 11 and 12 indicate a moderate to steep boundary offsetting some of the density units at the inferred position of the southern boundary of the basin. Profile 11 also indicates a moderate to steep discontinuity near the easternmost extent of the Hot Springs lineament.

\section{Profile 13}

Profile 13 (figs. 2 and 14) begins near well WT-24 on Yucca Mountain and continues onto proposed well ER-EC-7 in Beatty Wash. Profile 13 is constrained at the south by lithologies encountered in well WT-24 (D.C. Buesch, U.S. Geological Survey, written commun., 1999). To model the strong, negative magnetic anomaly at about $6 \mathrm{~km}$ (fig. 14) requires a thick, reverselymagnetized Tertiary section. This suggestion is in excellent agreement with Christiansen and others (1977) who estimate that about $900 \mathrm{~m}$ of welded Tiva Canyon Tuff acccumulated within the Claim Canyon caldera segment. The bulk magnetization, in part, also must be stronger than the Tiva Canyon Tuff on Yucca Mountain, indicating the presence of a significant thickness of the strongly magnetized Chocolate Mountain Tuff (Rosenbaum and Snyder, 1985). Byers and others (1976a) report that the tuff of Chocolate Mountain, a late phase of the Tiva Canyon Tuff, may be about $1 \mathrm{~km}$ thick in the Claim Canyon caldera. A block of the Eleana Formation must underly profile 13 in order to fully account for the large, positive magnetic anomaly at about $8 \mathrm{~km}$ (fig. 14). Geophysical models by Bath and Jahren (1984) and Brocher and others (1998) indicate that this formation does, indeed, underly parts of Yucca Mountain and vicinity. 


\section{DISCUSSION}

Previous gravity studies in southern Nevada over the last 30 years reveal one of the most pronounced gravity lows in the western United States situated over the Pahute Mesa - Oasis Valley area. Gravity measurements at 3,526 stations in the study area (fig. 1) clearly identify the extent and magnitude of this gravity low. Using a gravity inversion method, Hildenbrand and others (1999) separate the isostatic residual anomaly into basin and basement fields. The basin gravity field reflects variations in the thickness of low-density volcanic and sedimentary rocks, better characterizing the basins and features within them. Despite all of the available information, however, profiles such as those described herein and in Schenkel and others (1999) can provide new details as to the nature of the basin boundaries and other observed prominent geophysical features. The details are then correlated to known geology of the study area in order to test the validity of the geophysical models.

One of the general conclusions is that many basin boundaries are sharply defined, moderate to steeply dipping, and may reflect caldera boundaries. Caldera faults are indicated, to a first order, by undulations in the basement surface in the geophysical models and the basin thickness map (Hildenbrand and others, 1999). Some boundaries are discussed in detail below.

\section{Thirsty Canyon fault zone}

Because of its linearity and extent, Grauch and others (1997) speculated that the Thirsty Canyon lineament could represent a pre-caldera structure. Hildenbrand and others (1999) better define it by generating a basin thickness map, leading to their suggestion that a fault zone, rather than a single structure, is the source of the Thirsty Canyon lineament. Using available lithologic logs for wells PM-2, PM-3, UE20j, and UE20f, we produce geologic interpretations (fig. 15) for the same sections shown in figure 9. The models show that a zone of en echelon features (faults)

does, indeed, occur along the Thirsty Canyon lineament and it is best described as a fault zone. The width of the zone, which we will refer to as the Thirsty Canyon fault zone (TCFZ), appears to be on the order of 2 to $3 \mathrm{~km}$. The sub-parallel faults have produced step-like differential displacements similar to that of a caldera ring-fracture system (Smith and Bailey, 1968). Although many ring fracture systems are arcuate in shape, Smith and Bailey report that others appear as linear faults. A well exposed example of a ring-fracture system with differentially displaced blocks can be seen in the Coso Range of California (Duffield, 1975; Duffield and Bacon, 1981). In the Coso Range, the measured dip of the ring faults usually exceed $75^{\circ}$ (Duffield, 1975), a value that is in excellent agreement with estimates given above.

A classic model of caldera formation is that a voluminous eruption (many cubic kilometers) of pumice and ash is accompanied by, or closely followed by, collapse of a cylindrical block of crust along a ring fracture system to form the caldera. The size of the caldera is proportional to the volume of the ash-flow sheets produced. For some silicic volcanic centers, development of the ring-fracture system may actually precede climactic eruption and caldera collapse (see, for example, Smith and Bailey, 1968; Duffield, 1975; Mahood and Hildreth, 1983). In these cases, the ringfractures develop in response to inflation of the magma chamber and the fractures, themselves, may provide vents for the climactic eruptions. The TCFZ, if caused by caldera-producing eruptions, clearly preceded eruption of the Tiva Canyon/Rainier Mesa Tuffs which ponded along this barrier before overflowing toward the northwest (fig. 15). The TCFZ may also predate the unrecognized caldera resulting from eruption of either the 14.9 Ma Tub Spring Tuff or the 15.3 Ma Redrock Valley Tuff because of the large volume of older volcanics within the present boundaries of the caldera complexes. 

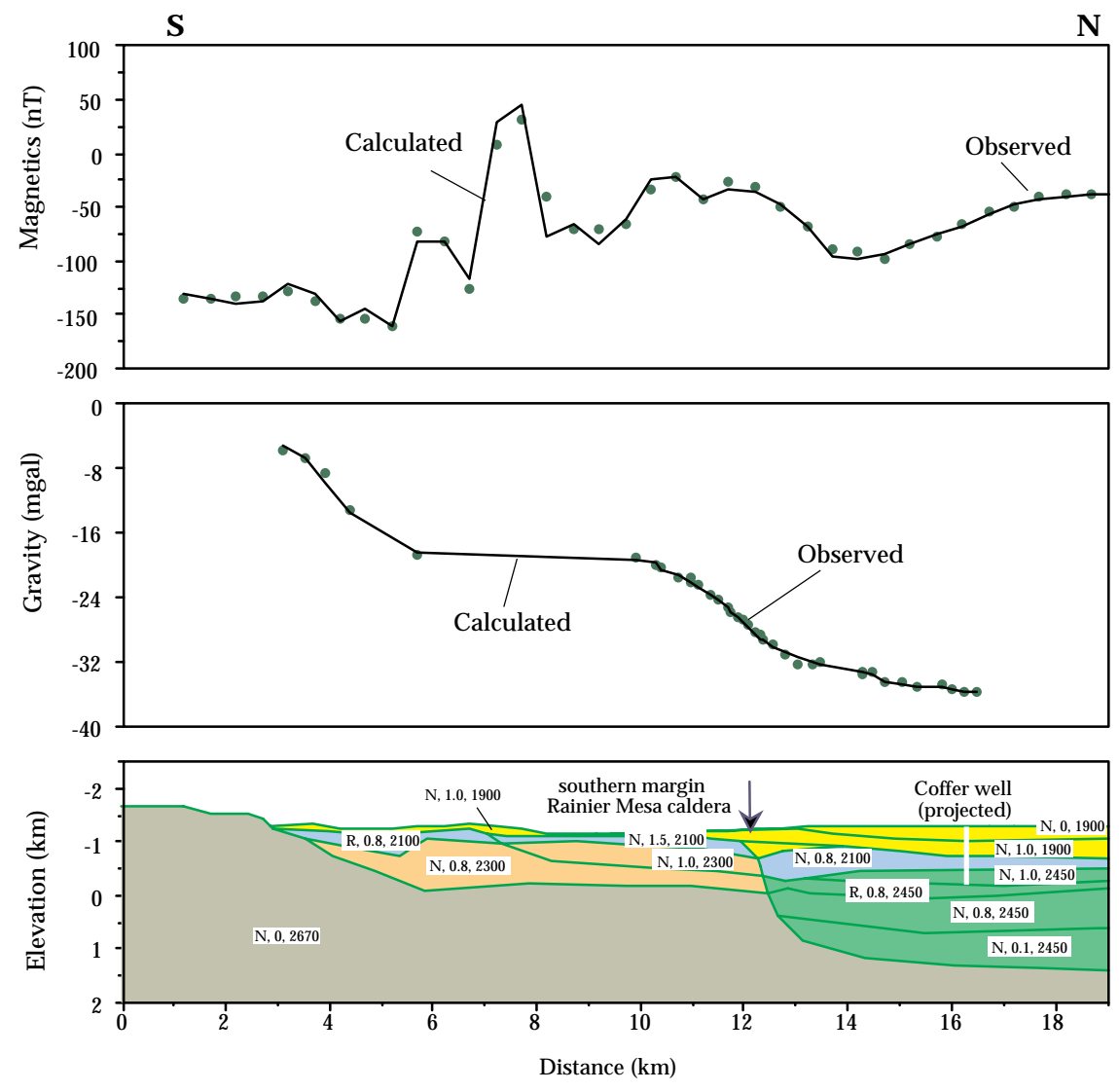

Figure 13. Geophysical model of the subsurface structure along profile 12. Also shown is the southern margin of Oasis Valley and the Rainier Mesa caldera. No vertical exaggeration. See figure 8 for additional explanation. 

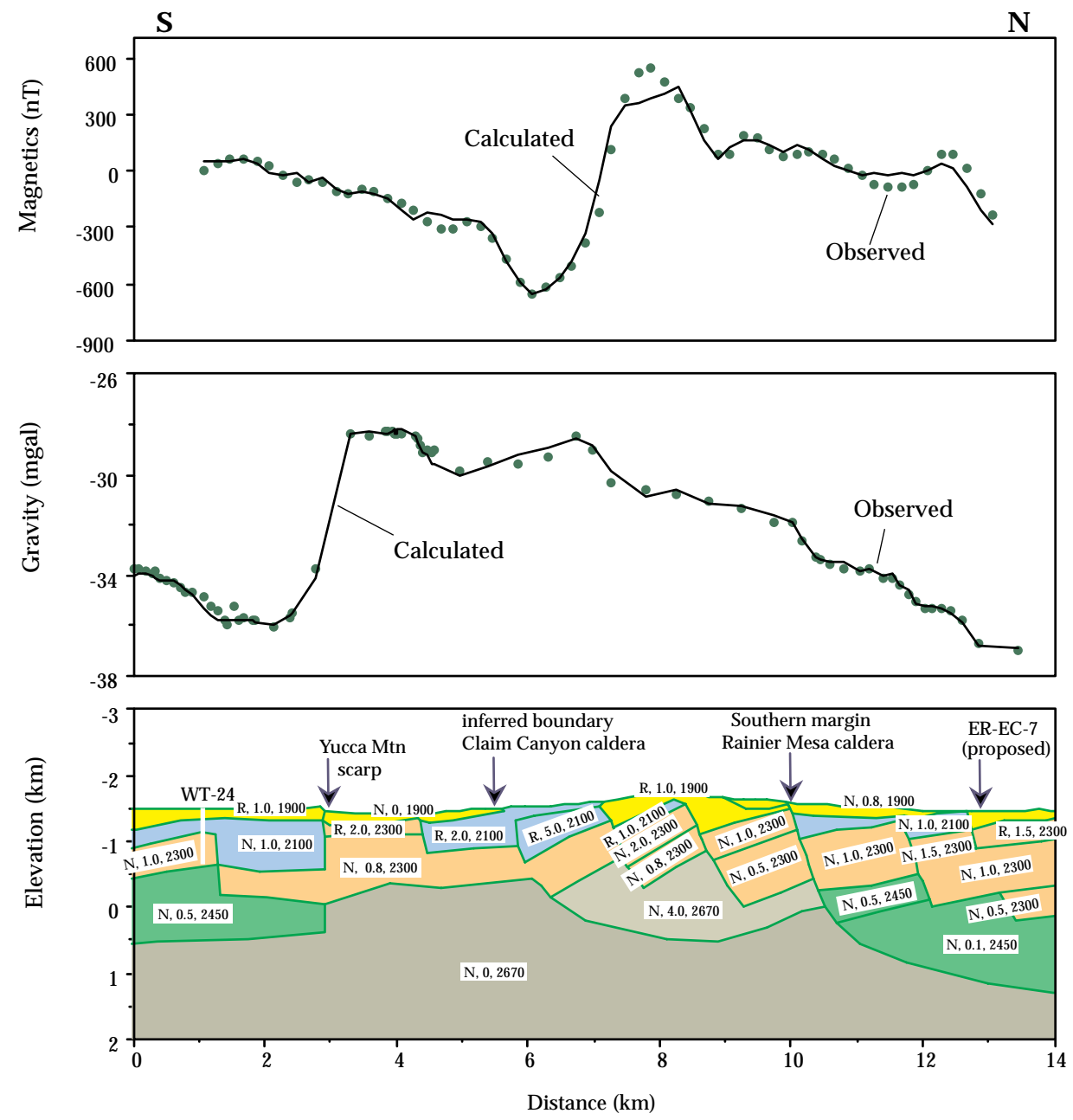

Figure 14. Geophysical model of the subsurface structure along profile 13. No vertical exaggeration. See figure 8 for additional explanation. 

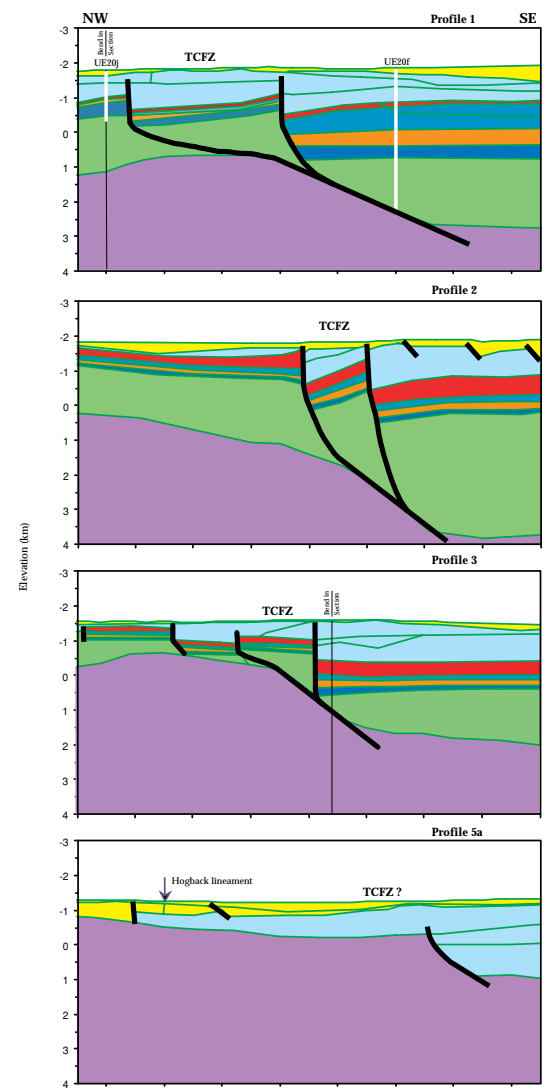

Figure 15. Geologic interpretation of the subsurface structure along the same profiles shown in figure 8 . Vertical exaggeration is 0.6. Colors are from figure 4. 
Evidence also has been found for pre-existing tectonic faults that led to piecemeal caldera collapse and related eruptions (Moore and Kokelaar, 1998). The topographic high represented by the Thirsty Canyon fault zone, therefore, could have initially developed during the early stages of Basin and Range faulting. This linear fault probably relieved vertical stresses related to caldera collapse and influenced the development of ring fracture systems, thus explaining the 2- to 3-km width of the TCFZ. The ancestral TCFZ apparently accommodated caldera growth, while at the same time, its step-like blocks formed a topographic barrier. Consequently, the linear western margins of calderas older than the 9.4 Ma Black Mountain form shallow fractures within the TCFZ. We thus define the TCFZ as both the deep ancestral faults and the overlying younger ring fractures related to the calderas.

Current data do not provide convincing evidence as to whether or not any faults of this ring fracture system remain tectonically active. We see no density contrasts that might indicate more recent activity offsetting the Rainier Mesa/Tiva Canyon Tuffs and younger deposits. MT data of Schenkel and others (1999), however, indicate that some of the major discontinuities, or faults, on Pahute Mesa may extend close to the surface. Many prominent, north-northeast-trending faults have been mapped on Pahute Mesa (see, for example, Orkild and others, 1969; Wahl and others, 1997). Rarely do any of these faults coincide with deeper structures. One exception is the $5 \mathrm{~km}-$ long Purse fault (see, for example, Laczniak and others, 1996, plate 4) that is directly above the easternmost basement fault of profile 2 (figs. $9 \mathrm{~b}$ and 15b). However, the downthrown side of the mapped surface fault is toward the west, whereas the downthrown side is toward the east on the geophysically inferred structure. Most of the surface faults, therefore, are probably shallow and confined to the uppermost parts of the volcanic sequence.

Micro-earthquakes have been measured and recorded for southern Nevada since 1908 (http://www.seismo.unr.edu/Catalog/catalog-search.html/). For the period from 1908 to 1990, many clusters occur in the immediate region, a small portion of which is shown in figure 16a. For the period from 1990 to 1998, however, many of the clusters disappear with one notable exception, the cluster along the TCFZ (fig. 16b). Not only does the cluster remain prominent, but there is some suggestion, perhaps more apparent than real, that the center migrated $2 \mathrm{~km}$ or more southwestward along the lineament. Although micro-earthquake clusters often occur randomly in time and space, the persistence of the Thirsty Canyon cluster suggests that it may be structurally controlled. We do not, at the present time, have a ready explanation for this interesting spatial relation between the TCFZ and an earthquake cluster. The cluster does occur, however, near the intersection of the TCFZ and a possible gravity lineament extending southeast from the Black Mountain caldera (fig. 5). Thus, the cluster may be an expression of stress relief at a block corner (Talwani, 1988).

\section{Basement Ridge}

The enclosed gravity high at about lat. $37^{\circ}$ 12' (figs. 2 and 5) might express a horst of preTertiary dense basement. We believe, however, that the block represents dense intrusions within the ring fractures of the Silent Canyon or Timber Mountain caldera complexes. Other such intrusions have been inferred to exist elsewhere within the Timber Mountain caldera complex (Kane and others, 1981). The area of this particular anomaly was apparently a structural high when the Tiva Canyon and Rainier Mesa Tuffs were erupted as evidenced by ponding of the reversed-polarity units on the southeast side of the feature (fig. 17). 

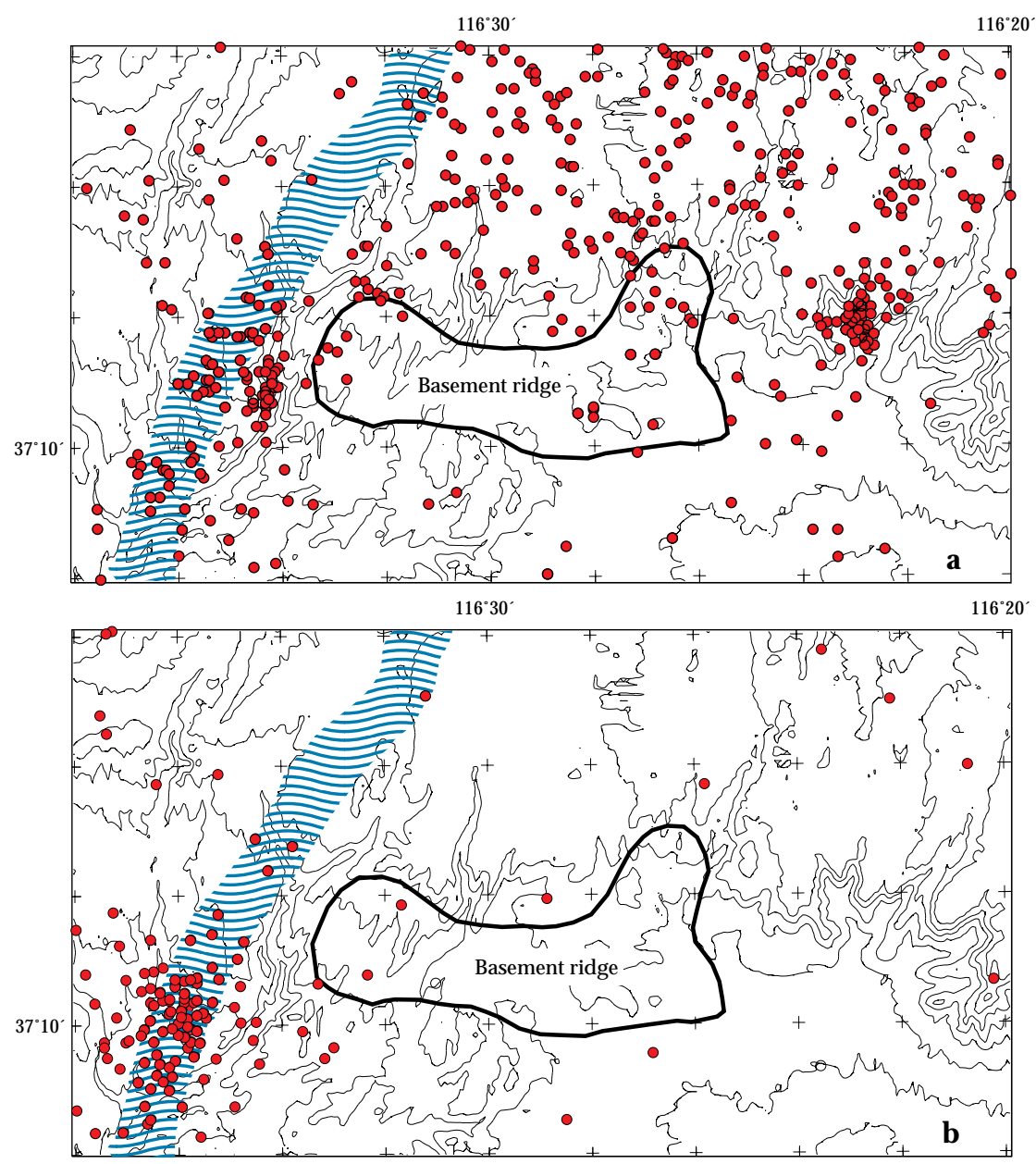

$0,10 \mathrm{KM}$

Figure 16. Location of micro-earthquakes (dots) in the Pahute Mesa area during the time intervals (a) 1908-1990 and, (b) 1990-1998. Solid lines are gravity lineaments shown in figures 2 and 5. Particularly note the cluster along the Thirsty Canyon fault zone (wavy lines). Contour interval is 100 meters. 

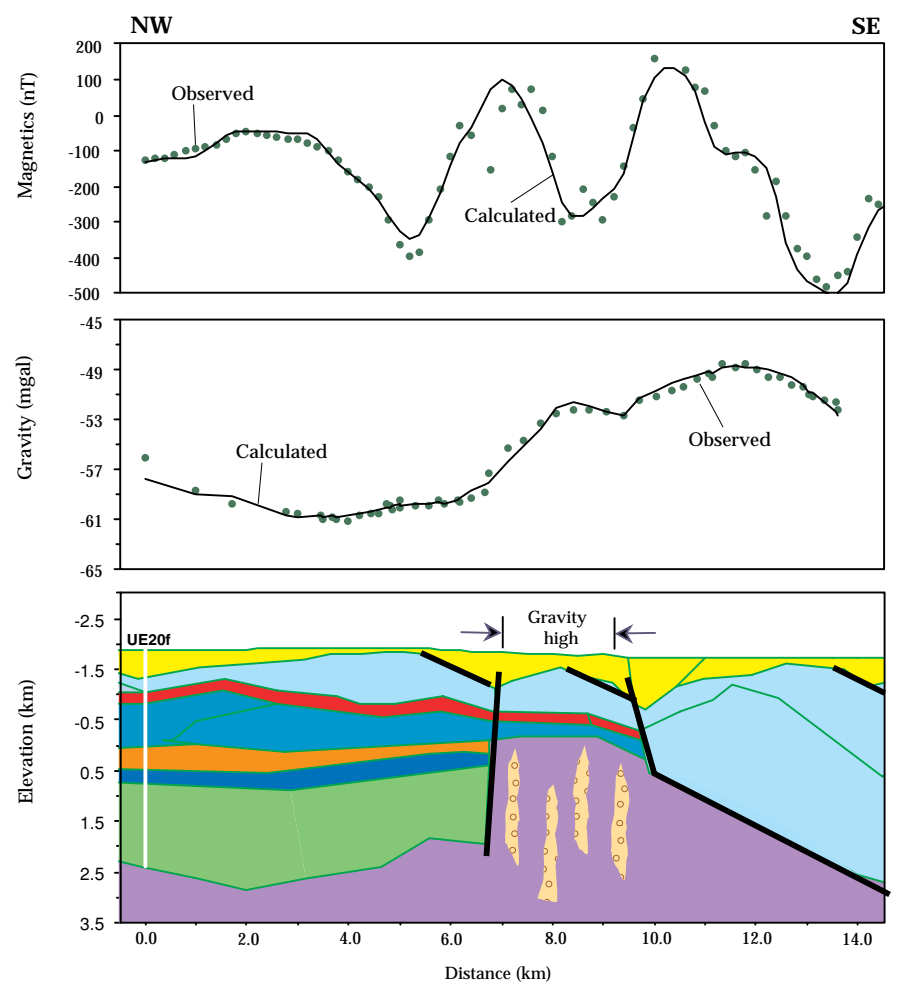

Figure 17. Geologic interpretation of the subsurface structure along profile 4. Pattern indicates block where multiple intrusions are inferred (see text). No vertical exaggeration. See figure 15 for additional explanation. 


\section{Oasis Valley Basin}

The relatively small Oasis Valley basin, or sub-basin (fig. 5), has long been recognized, but there has been little agreement as to its origin. Byers and others (1976) consider the basin to have resulted from collapse following eruption of the Ammonia Tanks Tuff. Christiansen and others (1977) consider it to be an earlier caldera segment related to the eruption of the Tiva Canyon Tuff. Sawyer and others (1994), however, suggest that the concept of an Oasis Valley caldera segment be abandoned. Recent geologic mapping (C.J. Fridrich, unpublished data, 1999) indicates that this basin is tectonic in origin and its boundaries coincide with the southern margin of the Black Mountain caldera on the north, the Hot Springs lineament on the south, the Hogback fault on the west, and the western margin of the Transvaal Hills to the east (figs. 2 and 5). Although it may still be part of the basin, the area to the north of the Colson Pond lineament is very shallow (fig. 5). The deepest part of the basin occurs in the southwest corner. Certainly, the Hogback fault and the western basin boundary coincide, at least in part. It is not clear on the basin thickness map (fig. 5), however, that the Hot Springs lineament is continuous to the south end of the Transvaal Hills. The southern boundary of the Oasis Valley basin, therefore, may not be the Hot Springs lineament but probably coincides with the southern structural margin of the Rainier Mesa caldera. Of particular interest within the basin is the north-south structural grain as expressed in the magnetic data (fig. 6).

\section{Colson Pond accommodation zone}

The TCFZ produces a well defined gravity anomaly from Pahute Mesa to very near the Colson Pond lineament (also see fig. 5) Its continuation southwest beyond Colson Pond is uncertain. Here, also, the structural grain changes from northeast-trending to an east-west trend. Gravity stations along profile 8 (appendix, p. 52) were reconnaissance in nature, and the resolution here is insufficient to adequately characterize this zone. No abrupt changes in basement depth occurs along profile 8 , although there is a small density contrast in the vicinity of an unnamed gravity lineament immediately north of the Colson Pond lineament. The break occurs within a reversed magnetic polarity unit, and the densest rocks are on the south side of the lineament.

\section{Hot Springs accommodation zone}

Modeling of profile 11 (appendix, p. 55) does yield some information as to the structure of this lineament although a detailed gravity study was not made. Modeling the regional gravity and magnetic coverage of this area reveals sharp discontinuities (faults?) near the lineament. Densest rocks appears on the south side of the lineament. Because the feature coincides with numerous hot springs, a better characterization of this lineament, and of the area between it and the southern boundary of the Oasis Valley basin is important to better understanding ground-water flow.

\section{Hogback fault}

The Hogback fault (fig. 2) clearly is one of the major tectonic/structural features in the study area. Modeling indicates that it is a high-angle structure and that the Oasis Valley basin is $4 \mathrm{~km}$ deeper on the east side of the fault near its southern end. The basin progressively shallows toward the north. Recent work (C.J. Fridrich, unpublished data, 1999) indicates that the fault was active long after caldera formation in the immediate area ceased.

\section{Profile 13}

Density contrasts (fig. 14) and inferred geologic structure (appendix, p. 57) show many moderately- to steeply-dipping surfaces (faults) along the length of profile 13. One of these seems to correspond with the continuation of the southern structural margin of the Oasis Valley basin (figs. 2 and 5). The northern scarp of Yucca Mountain appears to be a reactivation of a major fault at depth. The Claim Canyon caldera is anomalous because it does not overlie a basin and, in fact, 
the pre-Tertiary basement surface here is much shallower (Hildenbrand and others, 1999) than at either end of profile 13. The thickness of the reversed polarity section, however, is consistent with its being a thick intracaldera accumulation. The shallow basement indicates that structural resurgence has occurred within the Claim Canyon caldera (see, also, Byers and others, 1976, and Sawyer and others, 1994).

\section{POTENTIAL GEOHYDROLOGIC IMPLICATIONS OF INFERRED STRUCTURES}

As a result of caldera collapse, dense basement rocks occur at higher elevations outside caldera boundaries. The shallower presence of these shallow, dense rocks could have a significant impact on geohydrology. The basement, where it consists mainly of dense carbonate rock, serves as an important aquifer because of the many fractures contained within it and because dissolution by groundwater maintains fracture openings. Fracture flow also occurs in lava flows and densely welded ash-flow tuffs of the volcanic section, although some units will remain impermeable because the fractures may not be interconnected (Blankennagel and Weir, 1973).

Blankennagel and Weir (1973) described a water-level discontinuity beneath Pahute Mesa that creates a limited barrier to ground-water flow, and attributed this barrier to a permeability contrast (low permeability on the west, high permeability on the east). Distinct differences in major ion chemistry of water on either side of the feature (Blankennagel and Weir, 1973; Laczniak and others, 1996) support the concept of a limited-flow barrier. Blankennagel and Weir (1973) suggested that part of the barrier coincides with the western ring-fracture system of the Silent Canyon caldera. They also noted that aftershock epicenters from some nuclear explosions indicated possible extension of the barrier into the moat of the Timber Mountain caldera. Laczniak and others (1996), however, cautioned that the feature's existence and hydrologic significance were uncertain beyond the immediate area. O'Hagan and Laczniak (1996) depicted the feature as a broad zone (fig. 18) in order to represent its uncertain position and areal extent. 


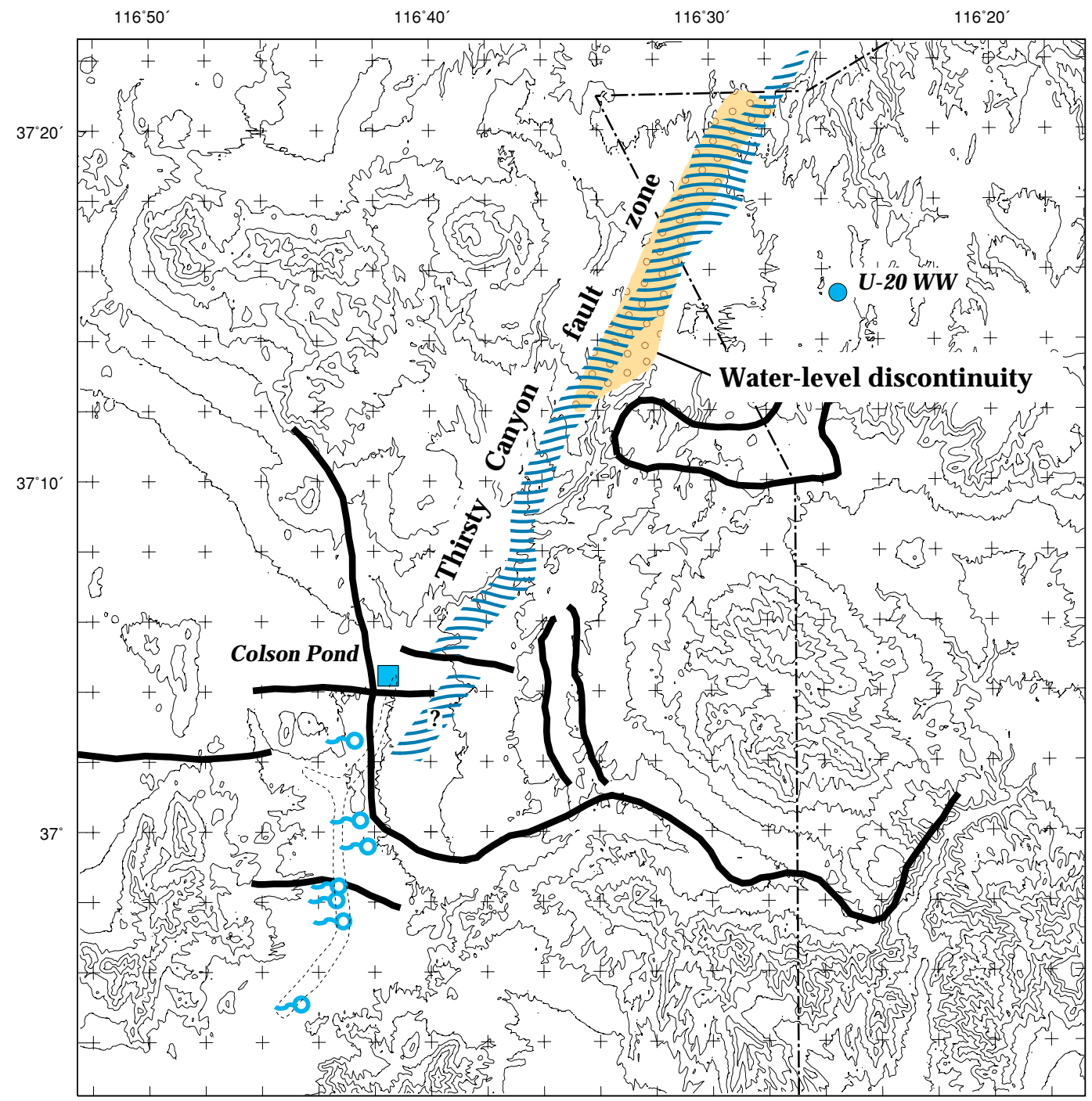

0

$25 \mathrm{KM}$

Figure 18. Map showing gravity lineaments, the inferred position of the Thirsty Canyon fault zone, and possible relationships to ground-water flow within the study area.

The remarkable coincidence of the O'Hagan and Laczniak limited-flow barrier with part of our inferred Thirsty Canyon fault zone (fig. 18) strongly indicates that the fault zone is a major control on ground-water flow from Pahute Mesa. The permeability contrast that they describe probably is caused by volcanic rocks on the northwest side of the Thirsty Canyon fault zone being more dense (fig. 15) than their intracaldera counterparts. If this is true, the flanks of the step faulted blocks in this area, which juxtapose rocks of differing permeability/density, would act as barriers to ground-water flowing westward across the NTS. Blankennagel and Weir (1973) speculated that the barrier deflects ground-water flow southwestward into Oasis Valley. 
Although permeability generally decreases with increasing density, dense rocks are easier to fracture and provide pathways for the movement of ground-water. Much fracturing is to be expected in a major fault zone such as the TCFZ, and these fractures generally will be aligned with the strike of the feature. Because it is a major fault zone, the TCFZ also should contain highly fractured rock and fault gouge, which may have been a channel-way for hydrothermal fluids due to the long-lived volcanic activity. Thus, hydrothermal alteration leading to conductive clays (Schenkel and others, 1999) may be a major factor within the shallow ring fractures of the TCFZ. Within the TCFZ, ground-water may be channeled southwestward, unless the fractures are sealed due to extensive alteration. Being an effective conduit that diverts water-flow into Oasis Valley also enhances the effectiveness of the TCFZ as a barrier to westward flow. Thus, the Thirsty Canyon fault zone simultaneously is both a barrier to, and a conduit for ground-water flow as suggested by Rowley (1998).

The interpretation that the TCFZ may be a significant feature influencing ground-water flow is supported by water chemistry data (J. Thomas, U.S. Geological Survey, written commun., 1998). Ground-water discharging from wells in the eastern and central parts of the Oasis Valley discharge area show nearly identical deuterium and ${ }^{18} \mathrm{O}$ values to those from well U-20 WW on Pahute Mesa (fig. 18). These stable isotope values differ significantly from other wells of the study area, specifically in the Springdale and Fortymile Canyon areas. The isotopic differences, corroborated in a general way by water chemistry (Blankennagel and Weir, 1973; Laczniak and others, 1996), is a strong indication that the eastern flank of the TCFZ is, indeed, a barrier to westward flow of ground-water.

Other major geophysical features in the study area probably also are significant factors influencing flow of ground-water. Colson Pond, for example, occurs near the intersection of the Thirsty Canyon fault zone with the Colson Pond and Hogback lineaments (fig. 18). The alignment of major springs in Oasis Valley parallel to the Hogback lineament is also noteworthy. Groundwater probably is deflected upward as it encounters shallow basement in the vicinity of Colson Pond and along the Hogback lineament. As with the case of the TCFZ, faulted basement along the Hogback fault and the southern margin of the Rainier Mesa caldera may act as barriers and deflect ground-water flow. Southeastward flow across the southern moat of the Rainier Mesa caldera remains a possibility, but water chemistry suggests that it does not reach as far east as Fortymile Canyon (J. Thomas, USGS, written commun., 1998). If the dense volcanic rocks along the southern margin are fractured and serve as aquifers, the fractures should again parallel the fault zone and act as conduits similar to those of the TCFZ. Ground-water would thus flow southwestward toward Bailey Hot Springs and Beatty. The uplifted basement and dense outflow sheets south of Beatty Wash should also contribute to the deflection of flow to the southwest, although flow directly south into Crater Flat cannot be totally discounted.

\section{CONCLUSIONS}

It is apparent from the available geophysical data that a number of very prominent, subsurface features/structures exist in the Pahute Mesa - Oasis Valley area. Most of the subsurface features probably are related to caldera-forming events. Modeling of the gravity and aeromagnetic data, along with the map of basin thickness (Hildenbrand and others, 1999) and MT data (Schenkel and others, 1999), have provided many new details as to the physical characteristics of the features identified by gravity and magnetic anomalies. Observed structures throughout the study area potentially could have a major impact on ground-water flow in the area as discussed in the previous section.

The Thirsty Canyon fault zone is one of the shortest and most direct routes for groundwater from the NTS to reach inhabited areas and, as such, warrants special attention for monitoring efforts. Continued definition of major structural features will help refine locations of subbasin boundaries and, possibly, contribute to developing a better conceptual understanding of groundwater flow in the study area. Pertinent future research in the Pahute Mesa and Oasis Valley area 
should include geophysical studies to better characterize the Hogback fault and the inferred accommodation zones at the southern boundary of the Oasis Valley basin and along the southern boundary of the Bullfrog Hills (Hot Springs lineament). A major structural boundary, as yet unidentified, may occur west of the Hogback fault because the stable isotope signature of groundwater in Oasis Valley and in the Springdale area are significantly different (J. Thomas, USGS, written commun., 1998). Future study may help evaluate if ground-water flows directly south across the caldera complex boundaries into Crater Flat, or is deflected southwest toward Beatty.

\section{REFERENCES}

Bath, G.D., 1968, Aeromagnetic anomalies related to remanent magnetism in volcanic rock, Nevada Test Site, in Eckel, E.B., ed., Nevada Test Site: Geological Society of America Memoir 110, p. 135-156.

Bath, G.D., and Jahren, C.E., 1984, Interpretations of magnetic anomalies at a potential repository site located in the Yucca Mountain area, Nevada Test Site: U.S. Geological Survey Open-File Report 84-120, 40 p.

Best M.G., Christiansen, E.H., Deino, A.L., Grommé, C.S., McKee, E.H., and Noble, D.C. 1989, Eocene through Miocene volcanism in the Great Basin of the western United States: New Mexico Bureau of Mines and Mineral Resources Memoir 47, p. 91-113.

Blakely, R.J., 1995, Potential theory in gravity and magnetic applications: Cambridge University Press, $441 \mathrm{p}$.

Blakely, R.J., and Connard, G.G., 1989, Crustal studies using magnetic data, in Pakiser, L.C., and Mooney, W.D., eds., Geophysical Framework of the Continental United States: Boulder, Colorado, Geological Society of America Memoir 172, p. 45-60.

Blankennagel, R.K., and Weir, J.E., Jr., 1973, Geohydrology of the eastern part of Pahute Mesa, Nevada Test Site, Nye County, Nevada: U.S. Geological Survey Professional Paper 712$\mathrm{B}, 35 \mathrm{p}$.

Brocher, T.M., Hunter, W.C., and Langenheim, V.E., 1998, Implications of seismic reflection and potential field geophysical data on the sructural framework of the Yucca Mountain-Crater Flat region, Nevada: Geological Society of America Bulletin, v. 110, p. 947-971.

Byers, F.M., and Cummings, D., 1966, Geologic map of the Scrugham Peak Quadrangle, Nye County, Nevada: U.S. Geological Survey Geologic Quadrangle Map GQ-695, scale $1: 24,000$.

Byers, F.M., Jr., Carr, W.J., Orkild, P.P., Quinlivan, W.D., and Sargent, K.A., 1976a, Volcanic suites and related cauldrons of Timber Mountain - Oasis Valley caldera complex, southern Nevada: U.S. Geological Survey Professional Paper 919, 70 p.

Byers, F.M., Jr., Carr, W.J., Christiansen, R.L., Lipman, P.W., Orkild, P.P., and Quinlivan, W.D., 1976b, Geologic map of the Timber Mountain caldera area, Nye County, Nevada: U.S. Geological Survey Miscellaneous Investigations Map I-891, scale 1:48,000.

Carroll, R.D., 1989, Density logging and density of rocks in Rainier Mesa area, Nevada Test Site: U.S. Geological Survey Open-File Report 89-329, 252 p.

Christiansen. R.L., and Noble, D.C., 1968, Geologic map of the Trail Ridge Quadrangle, Nye County, Nevada: U.S. Geological Survey Geologic Quadrangle Map GQ-774, scale $1: 24,000$.

Christiansen, R.L., Lipman, P.W., Carr, W.J., Byers, F.M., Jr., Orkild, P.P., and Sargent, K.A., 1977, The Timber Mountain-Oasis Valley caldera complex of southern Nevada: Geological Society of America Bulletin, v. 88, p. 943-959.

Duffield, W.A., 1975, Late Cenozoic ring faulting and volcanism in the Coso Range area of California: Geology, v. 3, p. 335-338.

Duffield, W.A., and Bacon, C.R., 1981, Geologic map of the Coso volcanic field and adjacent areas, Inyo County, California: U.S. Geological Survey Miscellaneous Investigations Map I-1200, scale 1:50,000. 
Ferguson, J.F., Cogbill, A.H., and Warren, R.G., 1994, A geophysical-geological transect of the Silent Canyon caldera complex, Pahute Mesa, Nevada: Journal of Geophysical Research, v. 99 , p. 4323-4339.

Frizzell, V.A., Jr., and Shulters, J., 1990, Geologic map of the Nevada Test Site, southern Nevada: U.S. Geological Survey Miscellaneous Investigations Map I-2046, scale 1:100 000 .

Grauch, V.J.S., Sawyer, D.A., Fridrich, C.J., and Hudson, M.R., 1997, Geophysical interpretations west of and within the northwestern part of the Nevada Test Site: U.S. Geological Survey Open-File Report 97-476, 45 p.

Grauch, V.J.S., Sawyer, D.A., Fridrich, C.J., and Hudson, M.R., 1999, Geophysical framework of the southwestern Nevada volcanic field and hydrologic implications: U.S. Geological Survey Professional Paper 1608 (in press).

Healey, D.L., 1968, Application of gravity data to geologic problems at Nevada Test Site, in Eckel, E.B., ed., Nevada Test Site: Geological Society of America Memoir 110, p. 147156.

Hildenbrand, T.G., Langenheim, V.E., Mankinen, E.A., and McKee, E.H., 1999, Inversion of gravity data to define the pre-Tertiary surface and regional structures possibly influencing ground-water flow in the Pahute Mesa-Oasis Valley region, Nye County, Nevada: U.S. Geological Survey Open-File Report 99-49, 26 p.

Hoisch, T.D., Heizler, M.T., and Zartman, R.E., 1997, Timing of detachment faulting in the Bullfrog Hills and Bare Mountain area, southwest Nevada: Inferences from ${ }^{40} \mathrm{Ar} /{ }^{39} \mathrm{Ar}, \mathrm{K}-$ $\mathrm{Ar}, \mathrm{U}-\mathrm{Pb}$, and fission track thermochronology: Journal of Geophysical Research, v. 102, p. 2815-2833.

Hudson, M.R., Sawyer, D.A., and Warren, R.G., 1994, Paleomagnetism and rotation constraints for the middle Miocene southwestern Nevada volcanic field: Tectonics, v. 13, p. 258-277.

Jachens, R.C., and Moring, B.C., 1990, Maps of the thickness of Cenozoic deposits and the isostatic residual gravity over basement for Nevada: U.S. Geological Survey Open-File Report 90-404, 15 p.

Kane M.F., Webring, M.W., and Bhattacharyya, B.K., 1981, A preliminary analysis of gravity and aeromagnetic surveys of the Timber Mountain area, southern Nevada: U.S. Geological Survey Open-File Report 81-189, 40 p.

Kersting, A.B., Efurd, D.W., Finnegan, D.L., Rokop, D.J., Smith, D.K., and Thompson, J.L., 1999, Migration of plutonium in ground water at the Nevada Test Site: Nature, v. 397, p. 56-59.

Laczniak, R.J., Cole, J.C., Sawyer, D.A., and Trudeau, D.A., 1996, Summary of hydrogeologic controls on groundwater flow at the Nevada Test Site, Nye County, Nevada: U.S. Geological Survey Water-Resources Investigations Report 96-4109, 59 p.

Langenheim, V.E., Ponce, D.A., Oliver, H.W., and Sikora, R.F., 1993, Gravity and magnetic study of Yucca Wash, southwest Nevada: U.S. Geological Survey Open-File Report 93586-A, $14 \mathrm{p}$.

Mahood, G.A., and Hildreth, W., 1983, Nested calderas and trapdoor uplift at Pantelleria, Strait of Sicily: Geology, v. 11, p. 103-106.

Mankinen, E.A., Hildenbrand, T.G., Roberts, C.W., and Davidson, J.G., 1998, Principal facts for new gravity stations in the Pahute Mesa and Oasis Valley areas, Nye County, Nevada: U.S. Geological Survey Open-File Report 98-498, 14 p.

McCafferty, A.E., and Grauch, V.J.S., 1997, Aeromagnetic and gravity anomaly maps of the southwestern Nevada volcanic field, Nevada and California: U.S. Geological Survey Geophysical Investigations Map GP-1015, scale 1:250,000.

McKee, E.H., 1971, Tertiary igneous chronology of the Great Basin of the western United States- Implications for tectonic models: Geological Society of America Bulletin, v. 82, p. 34973502 .

McKee, E.H., Noble, D.C., and Silberman, M.L., 1970, Middle Miocene hiatus in volcanic activity in the Great Basin area of the western United States: Earth and Planetary Science Letters, v. 8, p. 93-96. 
Minor, S.A., Orkild, P.P., Swadley, W.C., Warren, R.G., and Workman, J.B., 1997, Preliminary digital geologic map of the Springdale Quadrangle, Nye Co., Nevada: U.S. Geological Survey Open-File Report 97-93.

Minor, S.A., Sawyer, D.A., Wahl, R.R., Frizzell, V.A., Jr., Shilling, S.P., Warren, R.G., Orkild, P.P., Coe, J.A., Hudson, M.R., Fleck, R.J., Lanphere, M.A., Swadley, W.C., and Cole, J.C., 1993, Preliminary geologic map of the Pahute Mesa 30' x 60' quadrangle, Nevada: U.S. Geological Survey Open-File Report 93-299, 39 p.

Moore, I., and Kokelaar, P., 1998, Tectonically controlled piecemeal caldera collapse: A case study of Glencoe volcano, Scotland: Geological Society of America Bulletin, v. 110, p. 1448-1466.

O'Conner, J.T., Anderson, R.E., and Lipman, P.W., 1966, Geologic map of the Thirsty Canyon Quadrangle, Nye County, Nevada: U.S. Geological Survey Geologic Quadrangle Map GQ-524, scale 1:24,000.

O’Hagan, M.D., and Laczniak, R.J., 1996, Ground-water levels beneath eastern Pahute Mesa and vicinity, Nevada Test Site, Nye County, Nevada: U.S. Geological Survey WaterResources Investigations Report 96-4042, 1 sheet.

Orkild, P.P., Sargent, K.A., and Snyder, R.P., 1969, Geologic map of Pahute Mesa, Nevada Test Site and vicinity, Nye County, Nevada: U.S. Geological Survey Miscellaneous Investigations Map I-567, scale 1:48,000.

Phelps, G.A., Langenheim, V.E., and Jachens, R.C., 1998, Thickness of Cenozoic deposits of Yucca Flat inferred from gravity data, Nevada Test Site, Nevada: U.S. Geological Survey Open-File Report 99-310, 29 p.

Ponce, D.A., 1997, Gravity data of Nevada: U.S. Geological Survey Digital Data Series DDS-42, CD-ROM, $27 \mathrm{p}$.

Ponce, D.A., and Langenheim, V.E., 1995, Gravity and magnetic investigations of the Ghost Dance and Solitario faults, Yucca Mountain, Nevada: U.S. Geological Survey Open-File Report 95-521, 26 p.

Rosenbaum, J.G., 1993, Magnetic grain-size variations through an ash flow sheet: Influence on magnetic properties and implications for cooling history: Journal of Geophysical Research, v. 98 , p. $11,715-11,727$.

Rosenbaum, J.G., and Snyder, D.B., 1985, Preliminary interpretation of paleomagnetic and magnetic property data from drill holes USW G-1, G-2, GU-3, G-3, and VH-1 and surface localities in the vicinity of Yucca Mountain, Nye county, Nevada: U.S. Geological Survey Open-File Report 85-49, 73 p.

Rowley, P.D., 1998, Cenozoic transverse zones and igneous belts in the Great Basin, western U.S. -- Their tectonic and economic implications, in Faulds, G.E., and Stewart, J.H., eds., Accommodation Zones and Transfer Zones - The Regional Segmentation of the Basin and Range Province: Geological Society of America Special Paper 323, p. 195-228.

Russell, G.M., and Locke, G.L., 1996, Summary of data concerning radiological contamination at well PM-2, Nevada Test Site, Nye County, Nevada: U.S. Geological Survey Open-File Report 96-599, 84 p.

Sawyer, D.A., Fleck, R.J., Lanphere, M.A., Warren, R.G., Broxton, D.E., and Hudson, M.R., 1994, Episodic caldera volcanism in the Miocene southwestern Nevada volcanic field: Revised stratigraphic framework, ${ }^{40} \mathrm{Ar} /{ }^{39} \mathrm{Ar}$ geochronology, and implications for magmatism and extension: Geological Society of America Bulletin, v. 106, p. 1304-1318.

Schenkel, C.J., 1998, Magnetotelluric data in the Pahute Mesa and Oasis Valley area, Nye County, Nevada: U.S. Geological Survey Open-File Report 98-504, 70 p.

Schenkel, C.J., Hildenbrand, T.G., and Dixon, G.L., 1999, Magnetotelluric study of the Pahute Mesa and Oasis Valley region, Nye County, Nevada: U.S. Geological Survey Open-File Report 99-355, 46 p.

Scott, R.B., and Bonk, J., 1984, Preliminary geologic map of Yucca Mountain, Nye County, Nevada, with geologic sections: U.S. Geological Survey Open-File Report 84-494, scale $1: 12,000$. 
Simpson, R.W., and Jachens, .R.C., 1989, Gravity methods in regional studies, in Pakiser, L.C., and Mooney, W.D., eds., Geophysical Framework of the Continental United States: Boulder, Colorado, Geological Society of America Memoir 172, p. 35-44.

Simpson, R.W., Jachens, R.C., Blakely, R.J., and Saltus, R.W., 1986, A new isostatic residual gravity map of the conterminous United States with a discussion on the significance of isostatic residual anomalies: Journal of Geophysical Research, v. 91, p. 8348-8372.

Smith, R.L., and Bailey, R.A., 1968, Resurgent cauldrons, in Coats, R.R., Hay. R.L., and Anderson, C.A., eds., Studies in Volcanology: Boulder, Colorado, Geological Society of America Memoir 116, p. 613-662.

Snyder, D.B., and Carr, W.J., 1984, Interpretation of gravity data in a complex volcano-tectonic setting, southwestern Nevada: Journal of Geophysical Research, v. 89, p. 10,193$10,206$.

Talwani, P., 1988, The intersection model for intraplate earthquakes: Seismological Research Letters, v. 59, p. 305-310.

Trexler, J.H., Jr., and Cashman P.H., 1997, A southern Antler foredeep submarine fan: The Mississippian Elena Formation, Nevada Test Site: Journal of Sedimentary Research, v. 67, p. 1044-1059.

Trexler, J.H., Jr., Cole, J.C., and Cashman P.H., 1996, Middle Devonian-Missippian stratigraphy on and near the Nevada Test Site: Implications for hydrocarbon potential: American Association of Petroleum Geologists Bulletin, v. 80, p. 1736-1762.

U.S. Geological Survey, 1999, Digital geologic map and database of the Nevada Test Site and vicinity, Nye, Lincoln, and Clark Counties, Nevada, and Inyo County, California: U.S. Geological Survey Open-File Report (in press).

Wahl, R.R., Sawyer, D.A., Minor, S.A., Carr, M.D., Cole, J.C., Swadley, W.C., Laczniak, R.J., Warren, R.G., Green, K.S., and Engle, C.M., 1997, Digital geologic map of the Nevada Test Site area, Nevada: U.S. Geological Survey Open-File Report 97-140, scale $1: 120,000$.

Webring, M., 1985, SAKI-FORTRAN program for generalized linear inversion of gravity and magnetic profiles: U.S. Geological Survey Open-File Report 85-122, 29 p.

Weiss, S.I., and Noble, D.C., 1989, Stonewall Mountain volcanic center, southern Nevada: Stratigraphic, structural, and facies relations of outflow sheets, near-vent tuffs, and intracaldera units: Journal of Geophysical Research, v. 94, p. 6059-6074.

Winograd, I.J., and Thordarson, W., 1975, Hydrogeologic and hydrochemical framework, southcentral Great Basin, Nevada-California, with special reference to the Nevada Test Site: U.S. Geological Survey Professional Paper 712-C, 126 p. 


\section{APPENDIX}

Following are results of modeling gravity and aeromagnetic data for each of the profiles shown in figures 2 and 5, and discussed throughout the text. Here, the profiles are shown in their entirety. Each profile shows, from top to bottom, (1) observed (dots) and calculated (solid lines) values of magnetization, (2) observed (dots) and calculated (solid lines) values of gravity, (3) a geophysical model that accounts for the observed values of gravity and magnetization, and (4) an interpreted geologic model based on gravity, magnetization, density, and available geologic information from drillholes and surface geologic mapping. Densities shown in the geophysical models are: gray $=2670$, green $=2450, \tan =2300$, blue $=2100$, and yellow $=1900$ (all in $\left.\mathrm{kg} / \mathrm{m}^{3}\right)$. Thick, solid lines in the geologic sections are inferred faults. Colors here are from figure 4. No vertical exaggeration unless otherwise noted. 

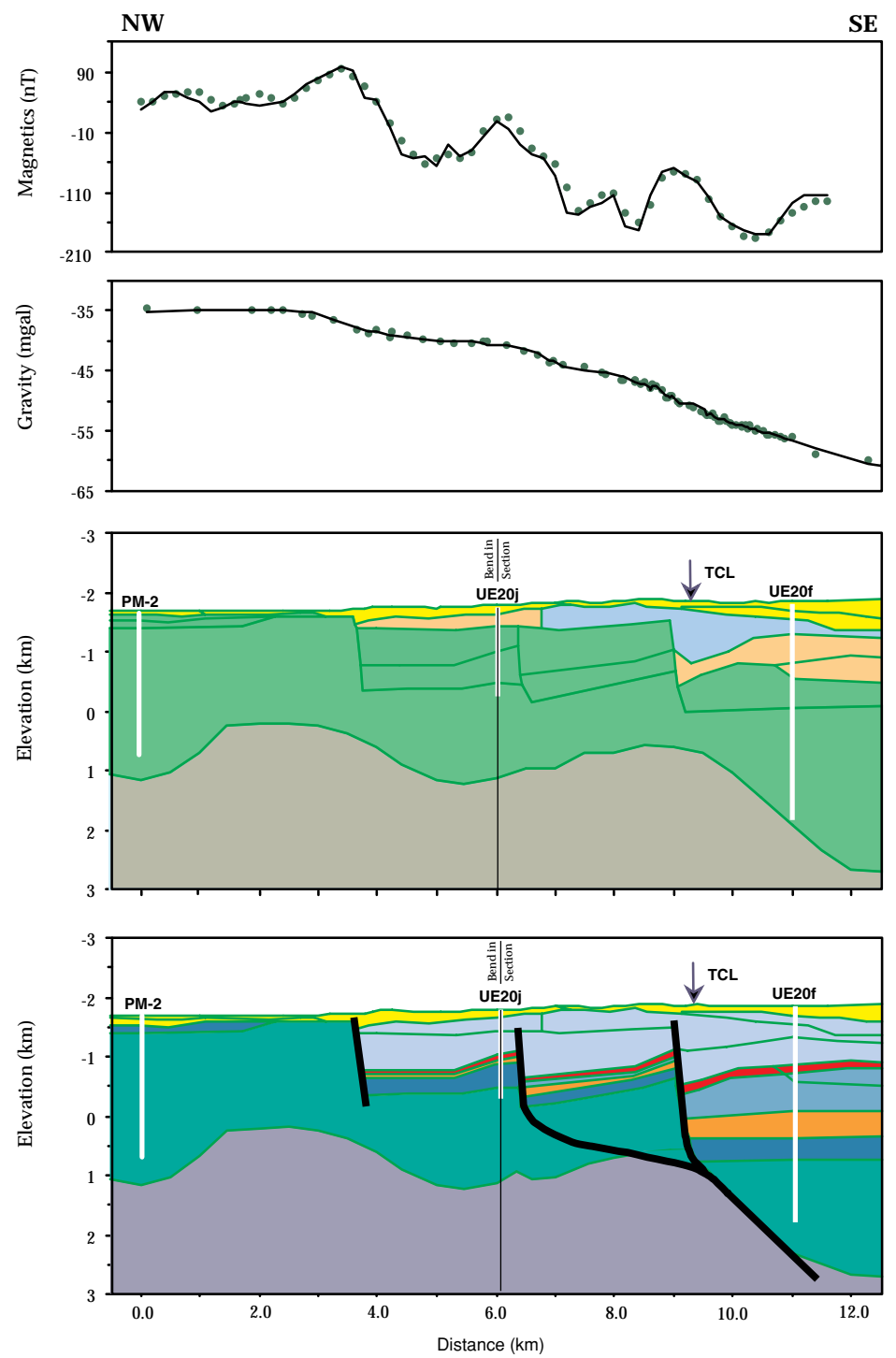

Profile 1 

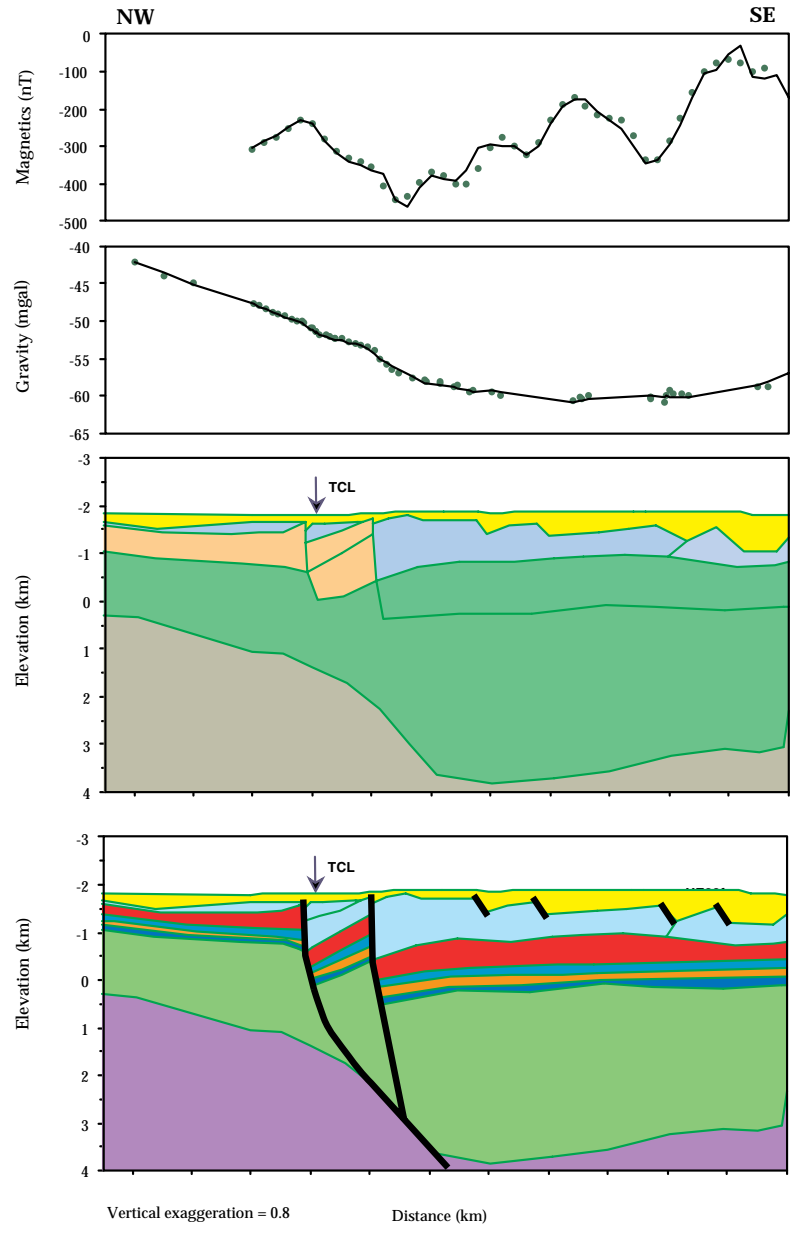

Profile 2 

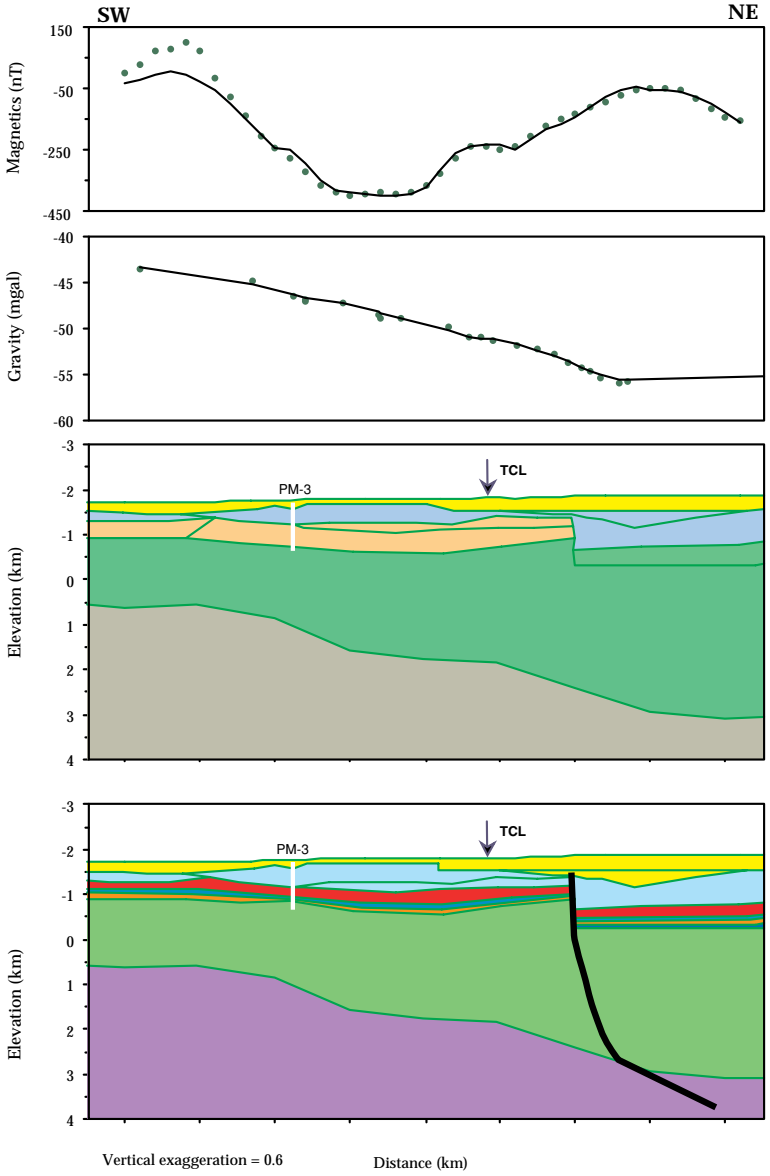

Profile 2a 

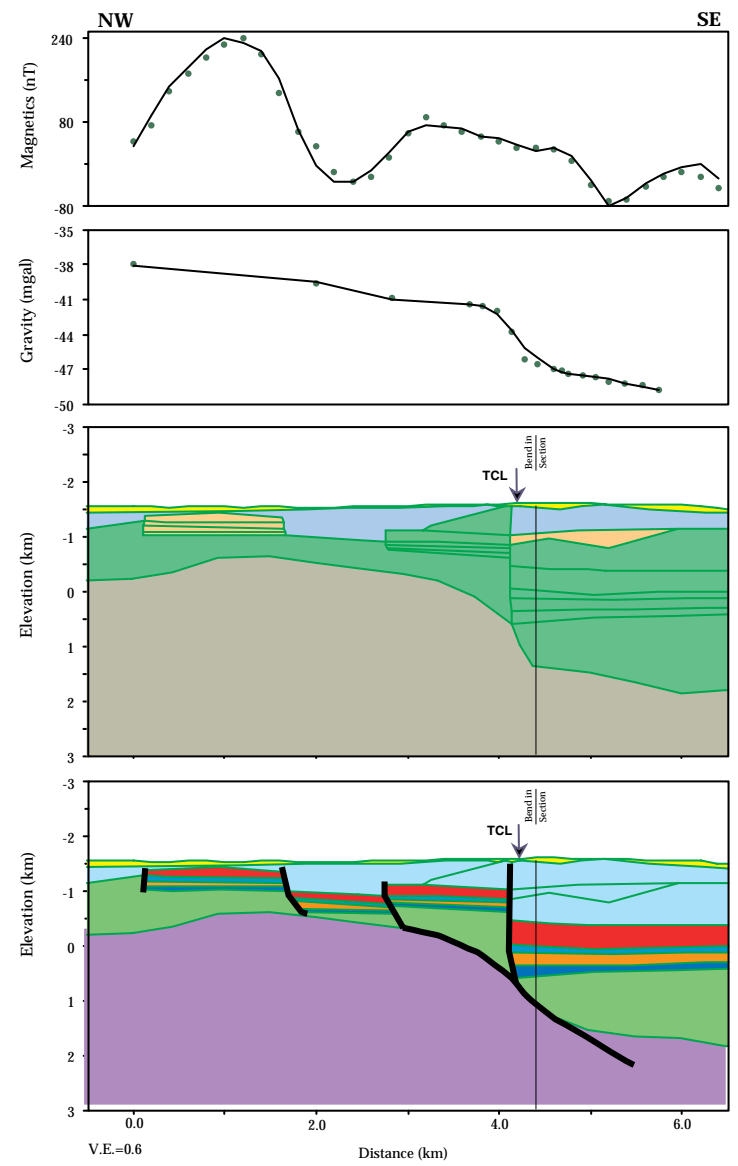

Profile 3 

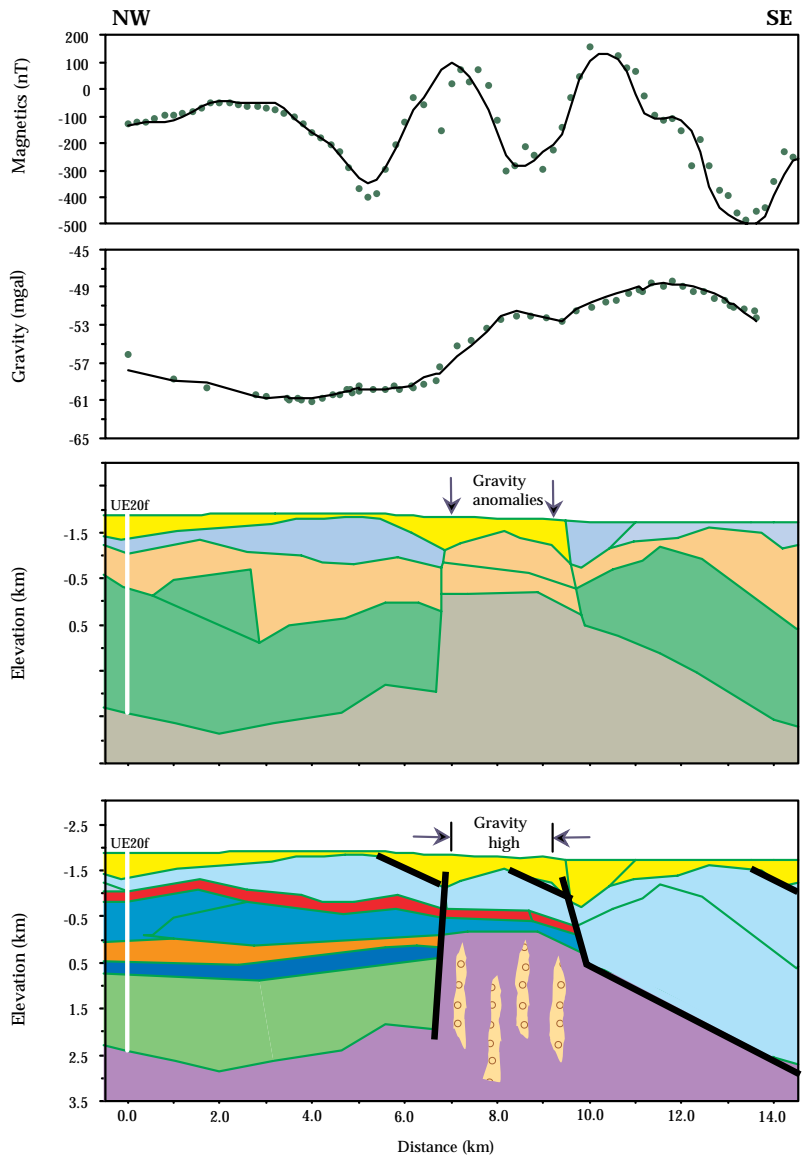

Profile 4 

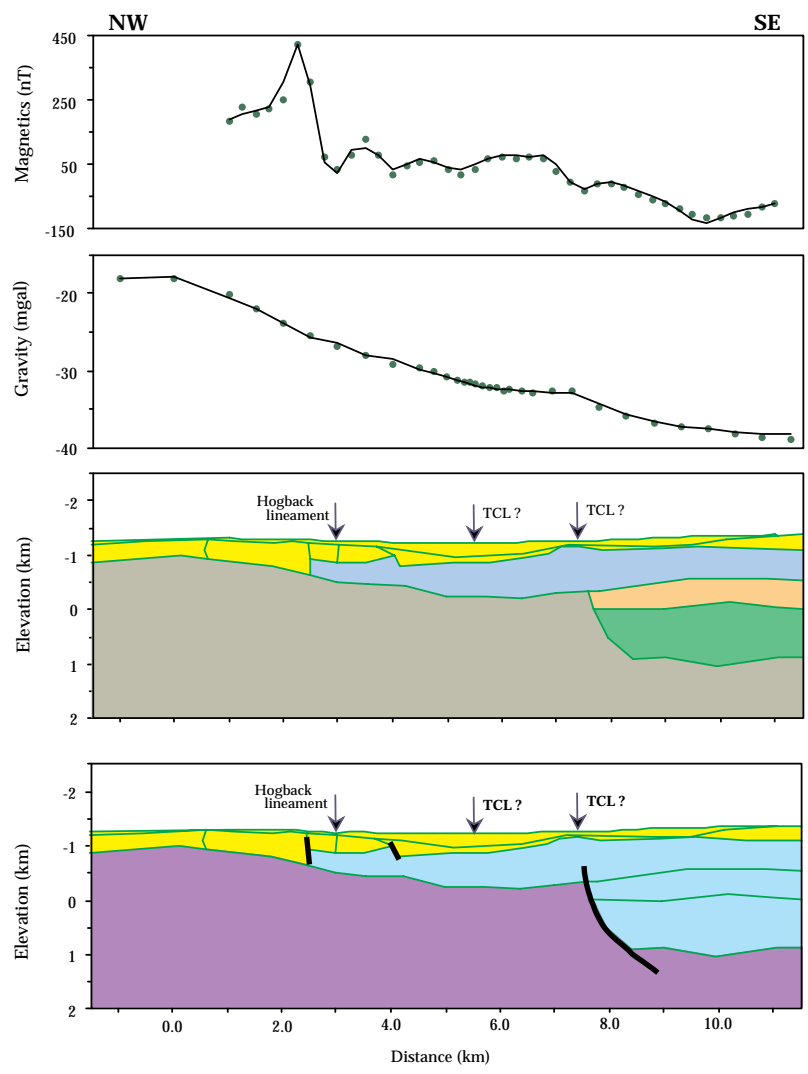

Profile 5a 

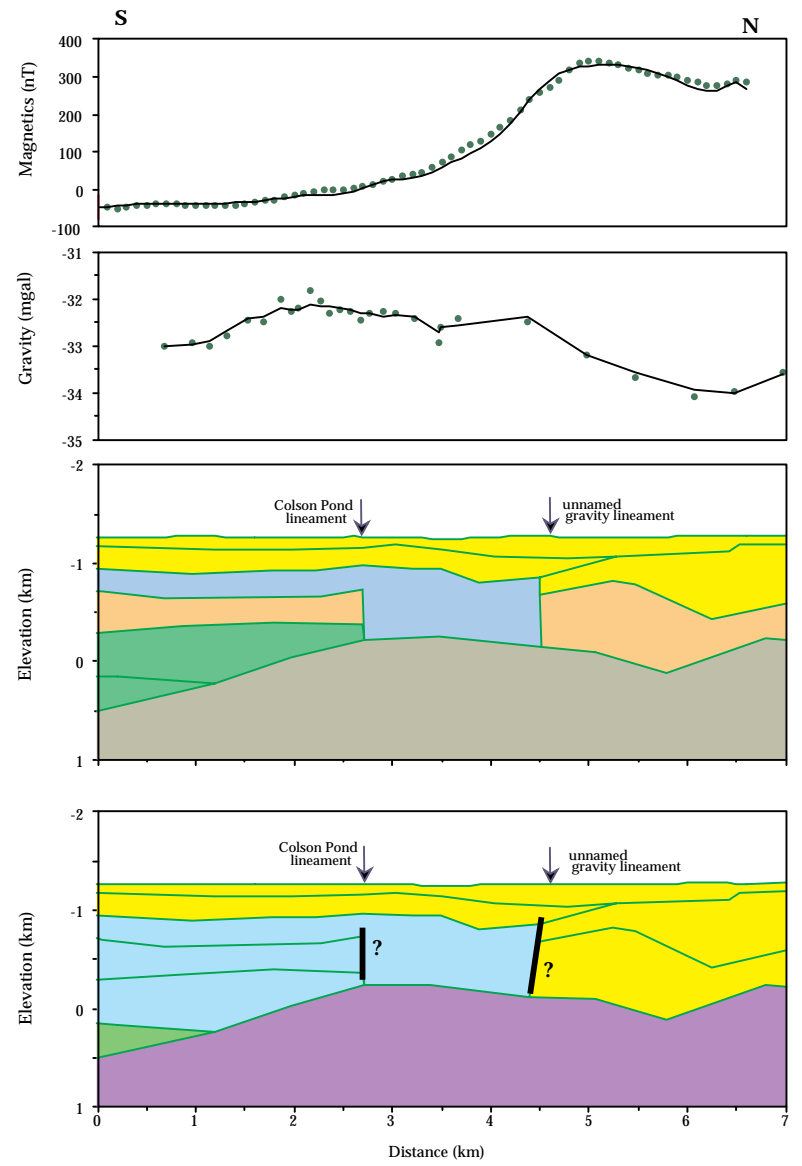

Profile 5b 

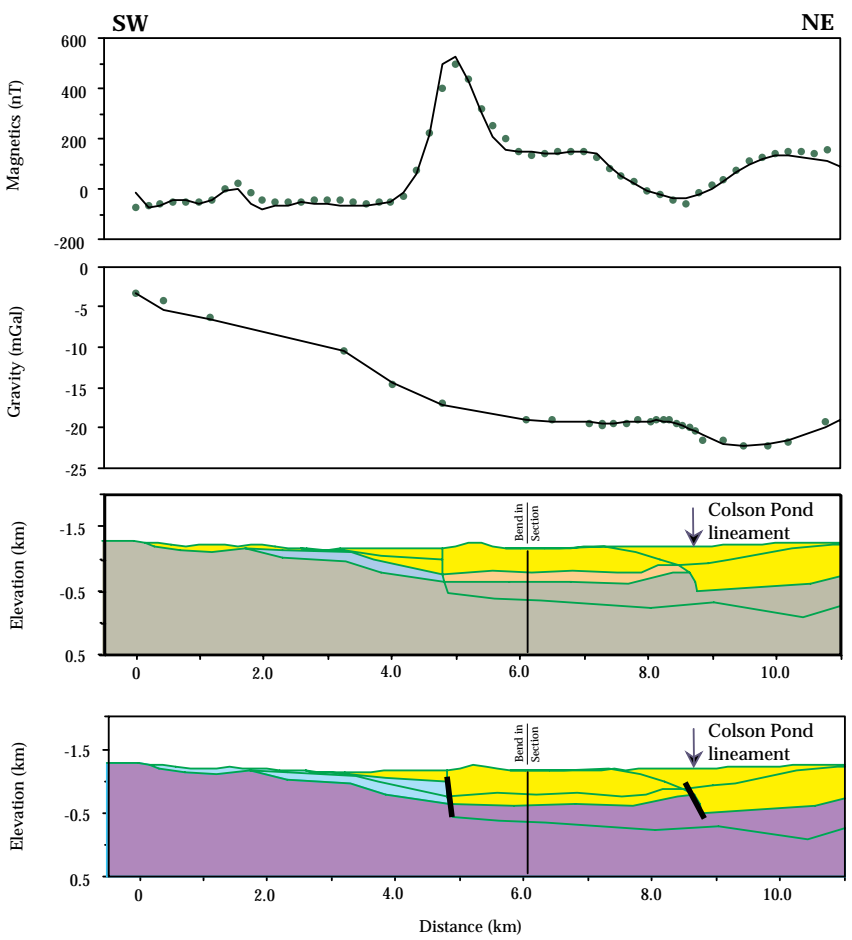

Profile 6 

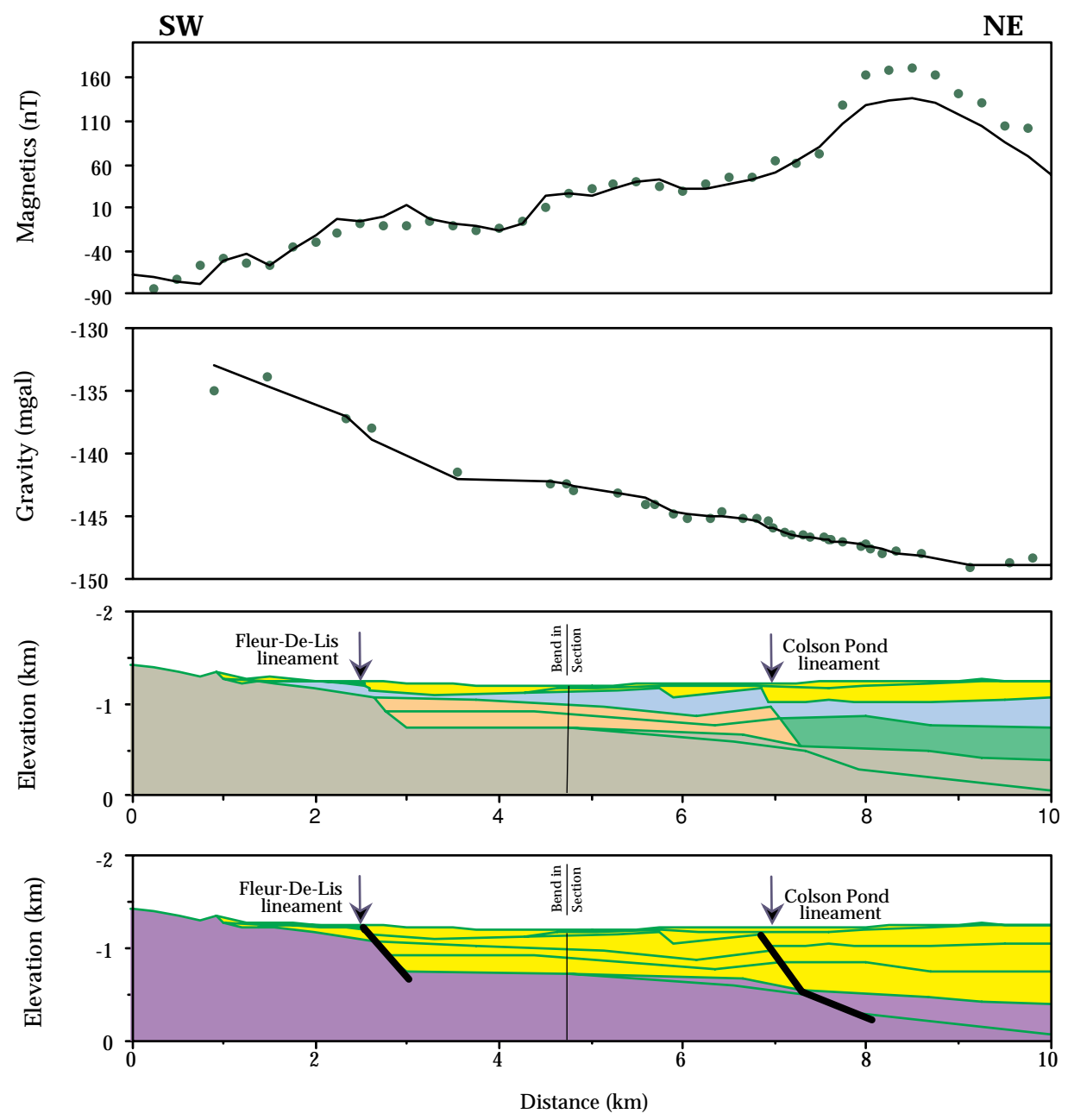

Profile 7 

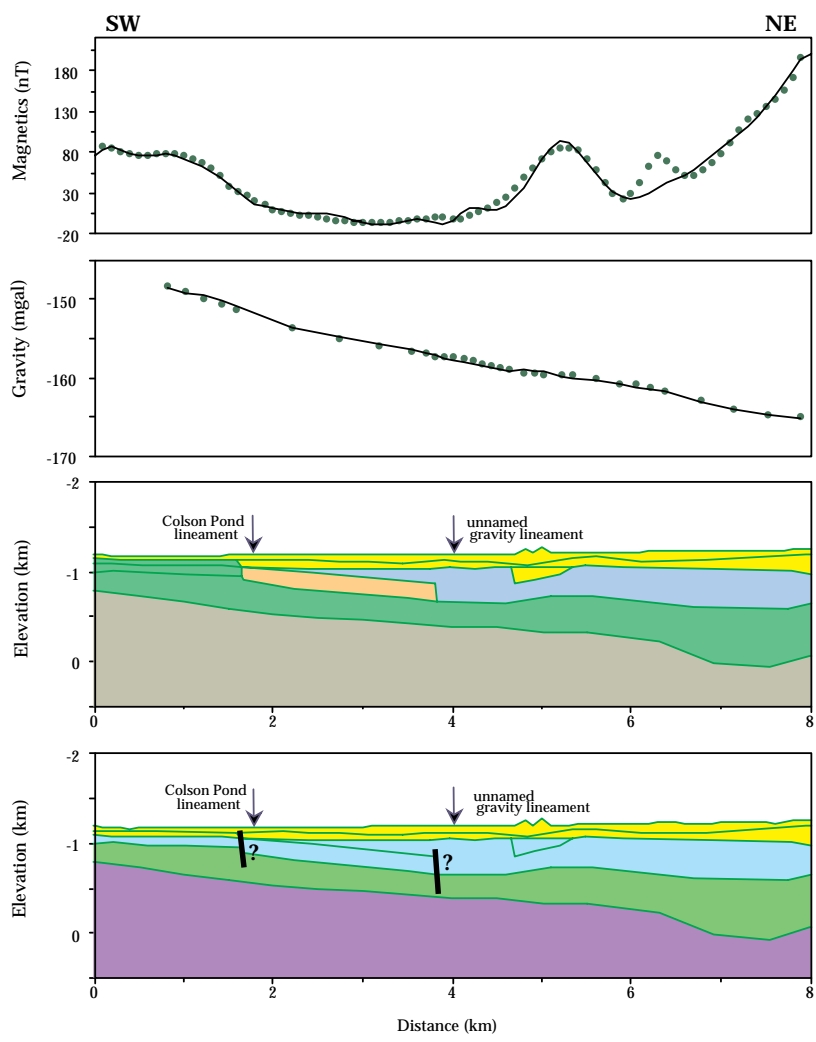

Profile 8 

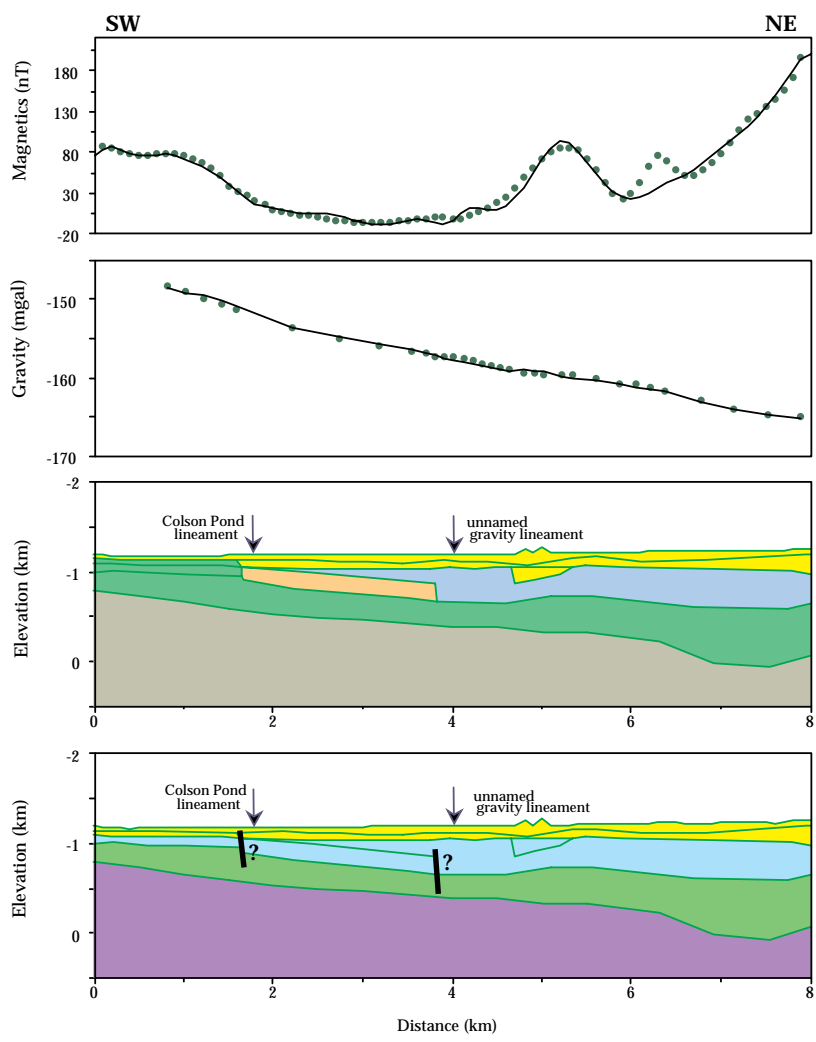

Profile 9 

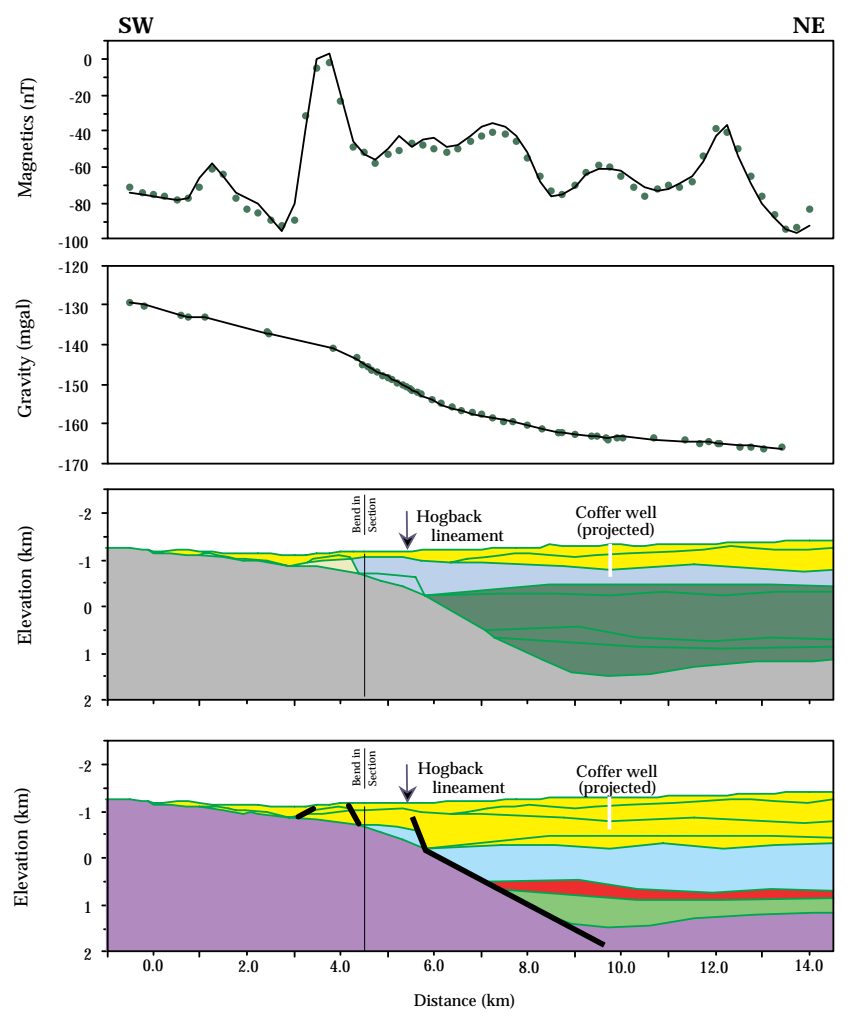

Profile 10 

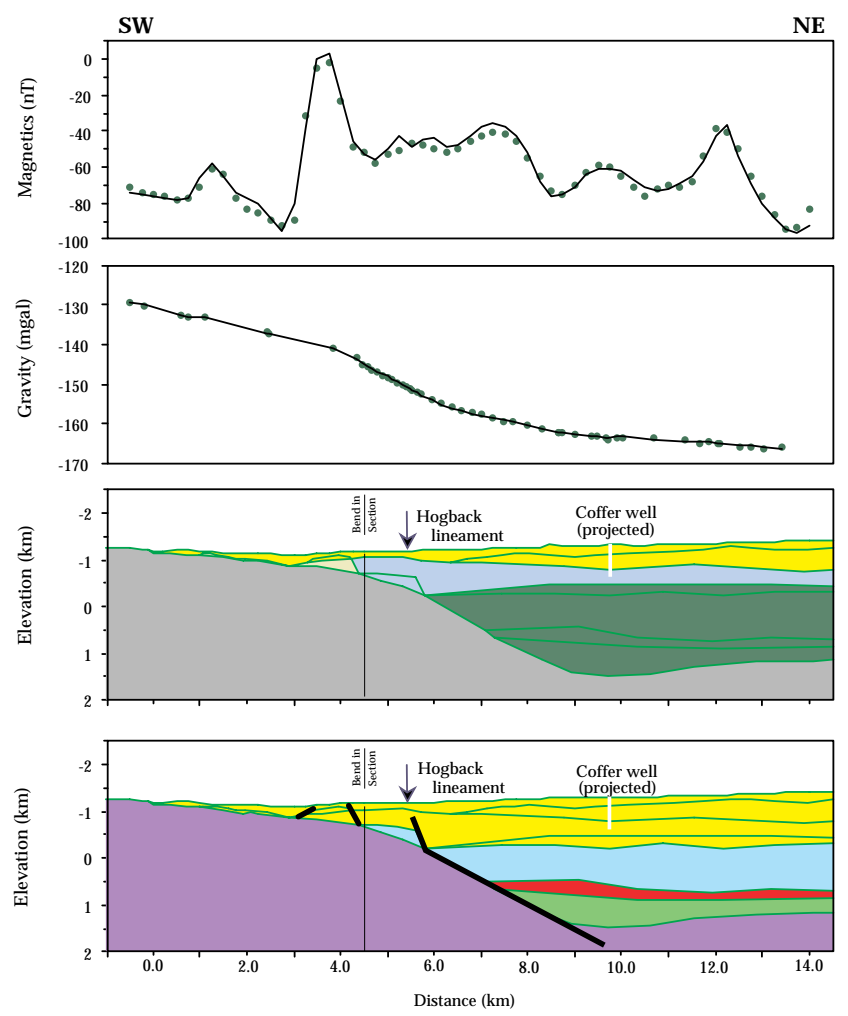

Profile 11 

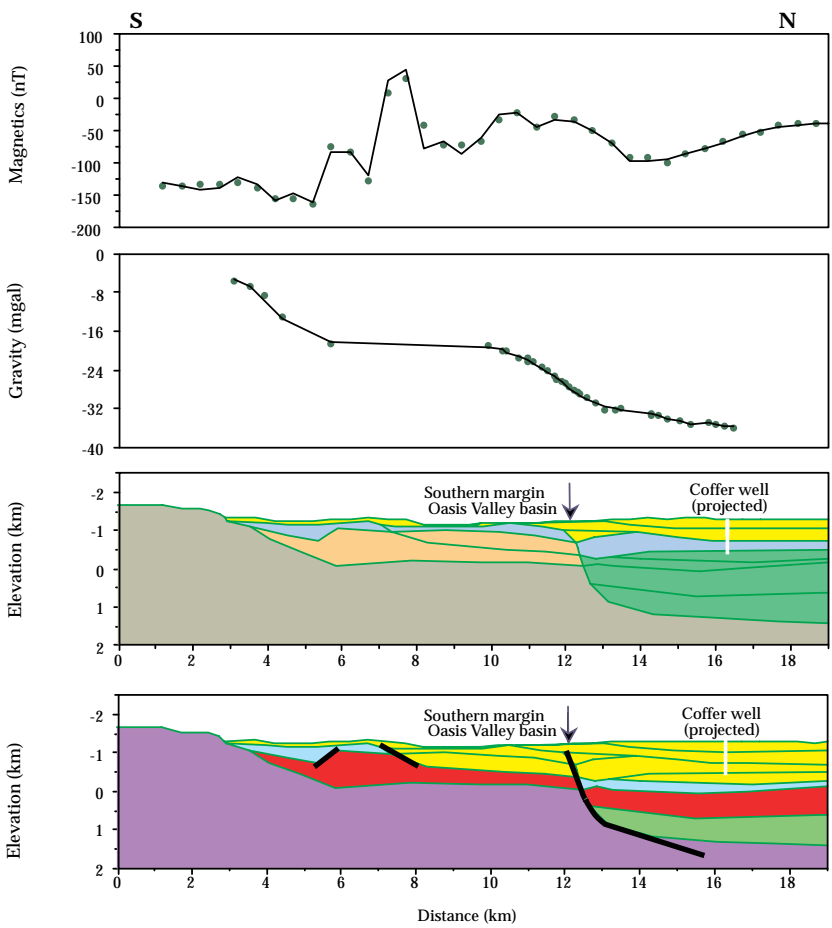

Profile 12 

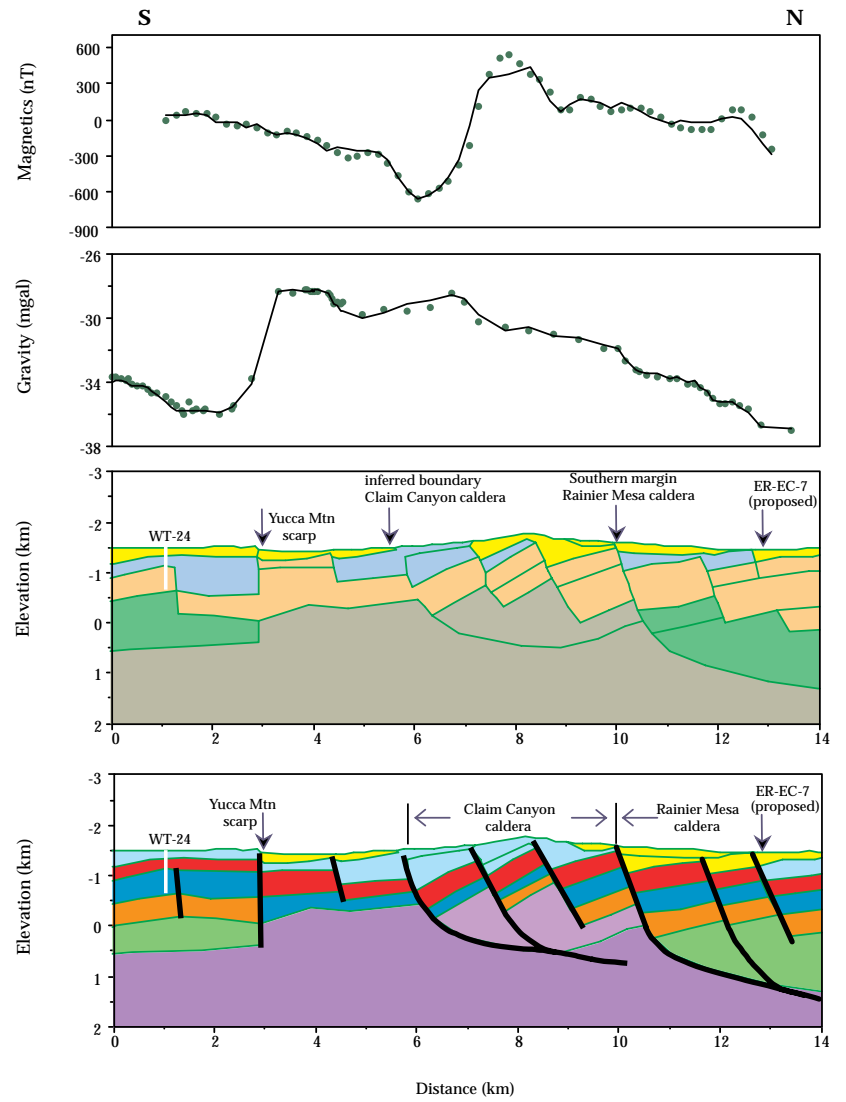

Profile 13 